\title{
Cyanobacterial Contribution to Travertine Deposition in the Hoyoux River System, Belgium
}

\author{
Julia Kleinteich $^{1,2}$ - Stjepko Golubic ${ }^{1,3,4}$ - Igor S. Pessi ${ }^{1}$ - David Velázquez ${ }^{1,5}$. \\ Jean-Yves Storme $^{4} \cdot$ François Darchambeau $^{6}$ - Alberto V. Borges ${ }^{6} \cdot$ Philippe Compère $^{7}$. \\ Gudrun Radtke $^{8} \cdot$ Seong-Joo Lee ${ }^{9} \cdot$ Emmanuelle J. Javaux $^{4} \cdot$ Annick Wilmotte ${ }^{1}$
}

Received: 5 August 2016 / Accepted: 10 January 2017 / Published online: 30 January 2017

(C) Springer Science+Business Media New York 2017

\begin{abstract}
Travertine deposition is a landscape-forming process, usually building a series of calcareous barriers differentiating the river flow into a series of cascades and ponds. The process of carbonate precipitation is a complex relationship between biogenic and abiotic causative agents, involving adapted microbial assemblages but also requiring high levels of carbonate saturation, spontaneous degassing of carbon dioxide and slightly alkaline $\mathrm{pH}$. We have analysed calcareous crusts and water chemistry from four sampling sites along the Hoyoux River and its Triffoy tributary (Belgium) in winter, spring, summer and autumn 2014. Different surface textures of travertine deposits correlated with particular microenvironments and were influenced by the local water flow. In all microenvironments, we have identified the cyanobacterium Phormidium incrustatum (Nägeli) Gomont as the organism primarily responsible for carbonate precipitation and traver-
\end{abstract}

Electronic supplementary material The online version of this article (doi:10.1007/s00248-017-0937-7) contains supplementary material, which is available to authorized users.

Julia Kleinteich

Julia.Kleinteich@gmail.com

1 InBios Center for Protein Engineering, University of Liège, B-4000 Liège, Belgium

2 Center for Applied Geosciences, University of Tübingen, D-72074 Tübingen, Germany

3 Biological Science Center, Boston University, Boston, MA 02215, USA

4 Palaeobiogeology, Palaeobotany, Palaeopalynology, Department of Geology, UR Geology B18, University of Liège, B-4000 Liège, Belgium tine fabric by combining morphological analysis with molecular sequencing (16S rRNA gene and ITS, the Internal Transcribed Spacer fragments), targeting both field populations and cultures to exclude opportunistic microorganisms responding favourably to culture conditions. Several closely related cyanobacterial strains were cultured; however, only one proved identical with the sequences obtained from the field population by direct PCR. This strain was the dominant primary producer in the calcareous deposits under study and in similar streams in Europe. The dominance of one organism that had a demonstrated association with carbonate precipitation presented a valuable opportunity to study its function in construction, preservation and fossilisation potential of ambient temperature travertine deposits. These relationships were examined using scanning electron microscopy and Raman microspectroscopy.
5 Department of Biology, Universidad Autónoma de Madrid, E-28049 Madrid, Spain

6 Chemical Oceanography Unit, Institut de Physique (B5), University of Liege, B-4000 Liège, Belgium

7 Department of Biology, Ecology and Evolution (BEE)/Centre of Aid for Research and Education in Microscopy (CAREM), University of Liège, B-4000 Liège, Belgium

8 Hessisches Landesamt für Naturschutz, Umwelt und Geologie, Rheingaustr. 186, D-65203 Wiesbaden, Germany

9 Department of Geology, Kyungpook National University, 1370 Sankyuck-dong, Daegu 702-701, South Korea 
Keywords Calcareous tufa · Culture support . Cyanobacteria $\cdot$ rRNA operon sequencing $\cdot$ Travertine deposition

\section{Introduction}

Cyanobacteria are the oldest oxygenic phototrophic microorganisms on Earth and the early contributors to most of the primary production and oxygenation of the planet. They have achieved a considerable morphological complexity for prokaryotic organisms, including multicellularity and cellular differentiation in structure and function [1]. Cyanobacteria displayed little change in cellular organisation and ecological integration over extended spans of the geologic time [2]. Microbial fossils of cyanobacteria, morphologically similar to modern forms, could be recognised in up to $2.1 \mathrm{Ga}$ $\left(\times 10^{9}\right.$ years $)$ old deposits [3-7], while traces of photosynthetic microorganisms preserved as laminated mats and stromatolites influenced the carbonate sediments throughout most of the early history of Earth [8-10]. Today, cyanobacteria continue to play a central role in promoting carbon and nitrogen cycling in marine and freshwater environments, while especially dominating in extreme habitats [11-13]. The study of modern forms helps in the interpretation of fossil records [5].

Involvement of cyanobacteria in deposition of carbonate in freshwater including the build-up of travertine or calcareous tufa occurs worldwide [14-17]. Travertine deposition subdivides the river flow by shifting it laterally to form barriers across the riverbed promoting uniform water distribution. The barriers are gradually elevated in the process. Deposition of travertine barriers over time changes the river flow into a series of ponds, accumulating behind the barriers and interconnected by cascades and waterfalls over these barriers. It is an ecologically significant landscape-forming process that creates new environments with a variety of microenvironments, which, in turn, support diverse specialised macroand microbiological assemblages. Travertine deposition is subject to cyclic and non-cyclic changes at different scales [18]. The process may improve the water quality along the river as suggested by increased light transmission and spectral shift in light as it penetrates through the water [19]. The location of travertine deposits and the formation of carbonate barriers is a sedimentary process guided by the growth response of some benthic organisms, primarily cyanobacteria, algae and mosses, to grow in turbulent water and promote sediment accumulation and consolidation [20]. It is in that sense a biogenic process, different from sedimentation that follows strictly physical laws of depositing particles in calm sections of the river. The resulting travertine barriers are therefore considered to act as freshwater reefs by structure and function [21].

The mechanism of travertine deposition is based on the same principles as the formation of microbialites, sensu
Burne and Moore [22], and stromatolites, sensu Riding [9], where the microorganisms participate by trapping, binding and encrusting the suspended particles carried by the water. The encrustation, which hardens the deposit, is accomplished by in situ carbonate precipitation from carbonate-supersaturated solution, which is also one of the conditions required for deposition of travertine [23]. Soil respiration within the watershed leads to an increase in $\mathrm{CO}_{2}$ concentration in the groundwater, with partial pressures of $\mathrm{CO}_{2}$ reaching up to values of 50,000 ppm in the study area (A.V. Borges, unpublished data), more than 12 times above the atmospheric value (400 ppm), causing calcium carbonate dissolution by the groundwater percolating through the base rock. Calcium carbonate $\left(\mathrm{CaCO}_{3}\right)$ is bound to precipitate again when the $\mathrm{CO}_{2}$ supersaturated water comes in contact with the air and the $\mathrm{CO}_{2}$ spontaneously degasses toward achieving the equilibrium with the atmosphere [24]. Gas exchange with the atmosphere is a slow process, but is significantly accelerated by the turbulence as the water passes through the rapids and cascades of the travertines. These are also the sites of increased exchange of nutrients and metabolites, and therefore these habitats are dominated by the organisms that promote travertine deposition.

Cyanobacteria and microscopic algae are the most common constituents of the biofilms coating the actively accreting travertine surfaces as well as those of mosses and submersed plants. Cyanobacterial trichomes may produce large amounts of exopolymer substances (EPS) generating exopolymer sheaths [25] with structural roles [26]. The microenvironments created by the polymeric sheaths can support certain mineral transformations [27]. Mineral precipitates, identified as $\mathrm{CaCO}_{3}$, are common to different cyanobacteria-based systems [26]. Precipitation of $\mathrm{CaCO}_{3}$ can occur within the EPS sheaths induced by metabolic activities (biologically induced mineralisation) or as result of environmentally driven mineralisation of the organic matrix (biologically influenced mineralisation) [28]. EPS often contain negative charged functional groups, which chelate cations from the running water such as $\mathrm{Ca}^{2+}$ [29]. Microsensor studies have documented the role of photosynthetic $\mathrm{CO}_{2}$ removal by phototrophic microorganisms [30]. The rates of travertine formation are in the order of millimetre annual increments of the deposit [17].

The travertine deposits are a target for fossilisation studies, including early diagenesis, due to high rates of carbonate precipitation in such systems. The process of fossilisation through calcification has been induced experimentally to study the deterioration of cellular and extracellular (EPS) products under controlled laboratory conditions [31]. Natural fossilisation and early diagenesis have been studied in freshwater carbonate deposits in carbonate regions for example in the USA and Europe [20, 32, 33] and non-carbonate environments of lacustrine lakes in Antarctica [34]. 
The investigations of cyanobacterial diversity in biofilms of German karstic rivers by combined morphological and molecular methods $[17,35]$ have shown a number of potential tufa-formers. However, many sequences obtained in those studies were unidentified or found to belong to phylotypes of ambiguous taxonomic identification. Cultivation attempts yielded relatively few strains, of which seven were deposited in a culture collection [36]. Therefore, to date, a direct link between a cultured isolate and natural populations of cyanobacteria involved in the carbonate precipitation in a travertine habitat has not been established.

The goals of the present study are to understand the particular, species-specific contribution of cyanobacteria to the precipitation of travertine or calcareous tufa in the Hoyoux river system in Belgium and further to understand the fossilisation potential of the dominant organism, recorded as mineral and organic textures in carbonate deposits.

\section{Materials and Methods}

\section{Site Description}

The Hoyoux system, a sub-basin of the Meuse River in Belgium, is $28 \mathrm{~km}$ long, has a catchment of $255 \mathrm{~km}^{2}$, an average slope of $9 \mathrm{~m} \mathrm{~km}^{-1}$ and is partially impacted by human intervention (Fig. 1). It is located on the Condroz Inlier. The geology is dominated by Devonian and Lower Carboniferous folded rocks composed of limestone and dolomite bedrocks. Both Hoyoux and Triffoy waterways cross several different strata deposited during Middle and upper Devonian [37]. At the time of sampling, the land cover was 58\% cropland, $27 \%$ forest and 15\% urban. The basin receives an average annual precipitation of $994 \mathrm{~mm}$, and the Hoyoux has an average freshwater discharge of $0.9 \mathrm{~m}^{3} \mathrm{~s}^{-1}$ (seasonal range between 0.2 and $13.0 \mathrm{~m}^{3} \mathrm{~s}^{-1}$ ). The Hoyoux drains 31 streams, among which the most representative ones are the Lilot (or Lileau), Triffoy, Vyle, Pailhe, Neuf Moulin and Bonne. In 2008, there were 37 travertine deposition sites along Hoyoux river (over a stretch of about $5 \mathrm{~km}$ length) and 19 along the Triffoy (over a stretch of about $1 \mathrm{~km}$ length) [37]. Travertine deposition during our investigation in 2014 was operating in both Hoyoux river and its Triffoy tributary, but some impacts due to human intervention have been observed.

\section{Field Analyses and Sampling}

Water analyses and travertine sample collection were carried out on travertine barriers at four sites along the Hoyoux River and its Triffoy tributary. Sample collection was carried out throughout an annual cycle on 17 October 2013, 3 February 2014, 20 June 2014, 8 August 2014 and 23 October 2014. Sampling of actively depositing travertine and local water for chemical analyses took place at four sampling sites (Fig. 1), each characterised by a series of carbonate barriers with cascades (except for site 1): Pont de Bonne (site 1) in the upstream part of the Hoyoux River, Moulin de Roiseux (site 2 ) in the middle part of the Hoyoux, the lower part of the Hoyoux tributary creek Triffoy (site 3) and at Ferme de Barse (site 4) in the lower section of the Hoyoux River. Travertine samples of 1 to $5 \mathrm{~cm}$ in diameter were cut to include the active surface as well as the interior to assess different layers and developmental stages of the deposit. From each sampling site, subsets of collected samples were stored frozen, air-dried or preserved in 3\% formaldehyde solution.

\section{Water Chemistry}

Water samples were collected in February and October 2014. Conductivity, water temperature, $\mathrm{pH}$ and dissolved oxygen were measured in situ at $30 \mathrm{~cm}$ depth with a portable field probe (YSI Pro-plus) that was calibrated using standard protocols. Water was collected using a 1.7-L Niskin bottle at $30 \mathrm{~cm}$ depth and samples for $\mathrm{CH}_{4} / \mathrm{N}_{2} \mathrm{O}$ were collected in borosilicate serum bottles, poisoned with $\mathrm{HgCl}_{2}$ and sealed with butyl stoppers and aluminium caps. $\mathrm{CH}_{4}$ and $\mathrm{N}_{2} \mathrm{O}$ concentrations were determined by headspace technique and gas chromatography using instrumentation and calibration as described in Borges et al. [38], with a precision of \pm 3.9 and $\pm 3.2 \%$, respectively. Samples for the determination of the partial pressure of $\mathrm{CO}_{2}\left(\mathrm{pCO}_{2}\right)$ were collected with four $60-\mathrm{mL}$ plastic syringes, and $\mathrm{pCO}_{2}$ was directly determined in the field by headspace technique and an infra-red gas analyser (Li-Cor Li-840) following the procedure described in Abril et al. [39] with a precision of $\pm 2.0 \%$. Samples for total alkalinity (TA) were filtered on $0.2-\mu \mathrm{m}$ polyethersulfone (PES) syringe filters and determined by titration [40]. Ammonium $\left(\mathrm{NH}_{4}{ }^{+}\right)$, nitrate $\left(\mathrm{NO}_{3}{ }^{-}\right)$and soluble reactive phosphorous (SRP) were determined with standard colorimetric methods [41].

\section{Light Microscopy}

Binocular microscopy (up to $\times 100$ magnification; Leica L2) with incident light was used to observe and photo-document the surface textures and porosity of carbonate encrustations and for preparation of samples for transmitted light microscopy, scanning electron microscopy and Raman microspectroscopy. Compound light microscopy (Leica DM LB2) was used for identification, photo-documentation and study of the distribution of microorganisms within carbonate crusts. Millimetre-size fragments from the surface of the encrustations were treated with dilute $(3 \%) \mathrm{HCl}$ to dissolve $\mathrm{CaCO}_{3}$. Samples for transmitted light microscopy were prepared from the insoluble residue, observed, measured and photo-documented. The procedure was repeated with fragments from the interior of the crust. Diversity and distribution of cyanobacteria was recorded with semi-quantitative estimates in 
Fig. 1 Map of the research area with travertine collection sites marked along the Hoyoux and Triffoy rivers, Belgium: 1 Pont de Bonne, 2 Moulin de Roiseux (mid-flow cascades), 3 Triffoy waterfalls, 4 Ferme de Barse. Forests are displayed in dark grey, agricultural land in white

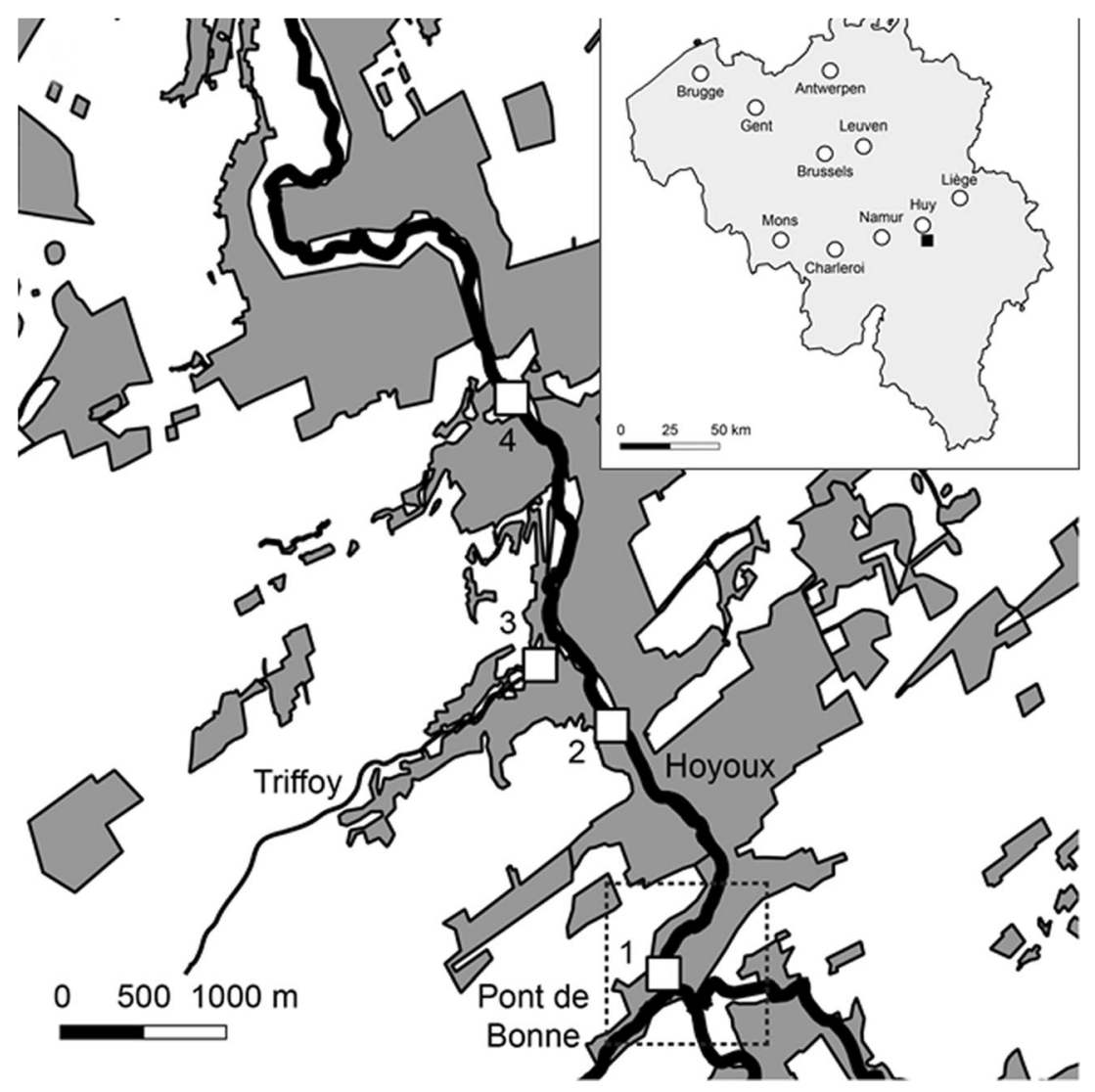

relation to the total insoluble organic and clay mineral residue (in percent of coverage representing percent of biomass). The populations were morphometrically characterised by measuring cell dimensions expressed as mean $\pm \mathrm{SD}(n>30)$.

\section{Scanning Electron Microscopy}

Preparations for SEM were made from subsamples of travertine crust preserved in the field with $3 \%$ formaldehyde solution in environmental water, according to the following procedures: (a) Subsamples were gradually dehydrated in an ethanol series, $\mathrm{CO}_{2}$ critical point dried (Leica EM CPD300) and Pt-coated (Balzers SCD 030 sputtering unit) for direct SEM observation of the biofilm and associated mineral precipitates on active travertine surfaces. (b) To remove the organic matter and observe clean mineral surface, subsamples were treated with Na-hypochlorite for 10 days before ethanol dehydration, air-drying and Pt coating. Observations and secondary electron images of both (a) and (b) subsamples were acquired in a SEM Jeol JSM-840A under $22 \mathrm{kV}$ accelerating voltage. (c) Vertical fractures and polished (by use of SiC paper; see below)/slightly etched surfaces of sections cut perpendicular to the crust were used for conventional SEM documentation of the mineral texture at depths in the concretions. (d) Subsamples were post-fixed for $2 \mathrm{~h}$ in $1 \%$ osmium tetroxide $\left(\mathrm{OsO}_{4}\right)$, 'en bloc' stained in $1 \%$ aqueous uranyl acetate and gradually dehydrated in an ethanol/propylene oxide series before embedding in epoxy resin (AGAR Low Viscosity Resin Kit, AGAR, R1078, hard mixture) with a step in a vacuum oven to improve resin penetration. These samples were sectioned perpendicular to the crust surface and the sections were mirror-polished with SiC paper (ESCIL up to PSA GR. 4000) and with non-aqueous $0.25-\mu \mathrm{m}$ diamond suspension (ESCIL 1/4PS-1/4MIC), then C-coated in a Balzers MED-010 evaporator for back-scattered electron (BSE) imaging in SEM and elemental $\mathrm{x}$-ray microanalysis. Sections included oncoids and encrusted branches to expose profiles and to follow changes of the deposit over time. The observations were realised in an FEI ESEM-FEG XL-30 under high vacuum conditions and $10 \mathrm{kV}$ accelerating voltage. Elemental $\mathrm{x}$-ray dispersive microanalyses and mappings were performed in the ESEM-FEG with a $129-\mathrm{eV}$ silicon drift detector (Bruker) and the Quantax 800 Esprit 1.9 software (Bruker).

\section{Raman Microspectroscopy}

Raman analyses were performed on polished thin sections of travertine and oncoids with a Renishaw In via Raman spectrometer coupled to a Leica DM 2500 confocal microscope with Ar-ion $50 \mathrm{~mW}$ monochromatic 514.5 and $785 \mathrm{~nm}$ as laser sources. Laser excitation was adjusted to an on-sample intensity of ca. $2 \mathrm{~mW}$ (measured with a Coherent Lasercheck 
Analyser) and focussed through $\times 50$ and $\times 100$ objectives to obtain a 1-2 $\mu \mathrm{m}$ spot size. Acquisitions were obtained with an 1800 and $1200 \mathrm{~mm}$ grating with an air-cooled $\left(-70{ }^{\circ} \mathrm{C}\right)$ $1024 \times 256$ pixel CCD (charge-coupled device) array detector. This method enabled a $2000 \mathrm{~cm}^{-1}$ spectral detection range. Beam centering and Raman spectra calibration were performed daily on a Si-Al microprocessor chip with a characteristic Si Raman band at $520.5 \mathrm{~cm}^{-1}$. Spectra were manipulated within Wire $3.4^{\mathrm{TM}}$ software. Point analysis measurements were made in static mode (fixed at $1150 \mathrm{~cm}^{-1}$ ). Raman mapping acquisition was also used (a) to detect the distribution of organic matter from the travertine surface through the carbonate deposit, to identify minerals and to assess the process of its fossilisation and its effect on calcification and mineral formation and (b) to analyse the nature and preservation of UVprotecting pigments $[42,43]$.

\section{Isolation and Culture}

Single-trichome cultures were established from different types of travertine material from field sites 2, 3 and 4, sampled during the field trip in February 2014 (Supplementary Table 1). Small fragments of travertine rock were distributed homogenously on sterile BG11 [44] agar plates containing $20 \mu \mathrm{g} \mathrm{mL}^{-1}$ cycloheximide. After visible growth, cyanobacterial trichomes were removed and transferred to a new plate until uni-cyanobacterial cultures were established. Cultures were kept at $15^{\circ} \mathrm{C}$ under low light conditions (ca. 2 klux, LS1 in Panasonic Plant Growth Chamber MLR-352). All seven uni-cyanobacterial isolates will be deposited in the public Belgian Co-ordinated Collections of Micro-organisms BCCM/ULC (Strain 2 is available as ULC392 and Strain 10 as UCL393). Genetic information of the 16S rRNA gene plus ITS sequence was obtained from all isolates as described below.

\section{Molecular Characterisation}

After collection, samples for DNA analysis were stored frozen at $-20{ }^{\circ} \mathrm{C}$. Genomic DNA from environmental material (site 2 and 3, from field trips in June and August, Supplementary Table 1) as well as from cultured isolates (see above) was extracted using the PowerBiofilm DNA Isolation Kit (MOBIO, Carlsbad, USA), according to instructions from the manufacturer. For two samples (MOD14 and 15, from the Triffoy and the Hoyoux, respectively), material collected directly from the travertine surface (upper $1 \mathrm{~mm}$ ) as well as material from a deeper section were extracted. Two PCR reactions were performed on all DNA extracts to amplify the $16 \mathrm{~S}$ rRNA gene as well as the ITS spacer between the $16 \mathrm{~S}$ rRNA and the 23S rRNA genes. The primer combinations $27 \mathrm{~F}$ and $809 \mathrm{R}$ [45] as well as $359 \mathrm{~F}$ and 23S30R [46, 47] were used in a PCR reaction containing $1 \times$ Phusion High-Fidelity
PCR Master Mix (Thermo Scientific, Waltham, USA), supplied with $0.5 \mu \mathrm{M}$ of each primer and $2 \mu \mathrm{L}$ of DNA per reaction. The cycling conditions for the $27 \mathrm{~F} / 809 \mathrm{R}$ primer pair were at $98^{\circ} \mathrm{C}$ for $2 \mathrm{~min}$, followed by 35 cycles with $98^{\circ} \mathrm{C}$ for $30 \mathrm{~s}, 58^{\circ} \mathrm{C}$ for $45 \mathrm{~s}$ and $72{ }^{\circ} \mathrm{C}$ for $50 \mathrm{~s}$, with a final elongation of $5 \mathrm{~min}$ at $72^{\circ} \mathrm{C}$. For the $359 \mathrm{~F} / 23 \mathrm{~S} 30 \mathrm{R}$ primer pair, the $\mathrm{PCR}$ conditions were as follows: $98{ }^{\circ} \mathrm{C}$ for $2 \mathrm{~min}$, followed by 35 cycles of $98^{\circ} \mathrm{C}$ for $30 \mathrm{~s}, 68^{\circ} \mathrm{C}$ for $30 \mathrm{~s}$ and $72^{\circ} \mathrm{C}$ for $90 \mathrm{~s}$, and a final elongation at $72^{\circ} \mathrm{C}$ for $5 \mathrm{~min}$. The amplified fragments were run on an agarose gel and the PCR products purified using the GeneJet PCR Purification Kit (Thermo Scientific, Waltham, USA). The PCR fragments were sequenced using several primers (27F, 359F, 359R, 809R, 1092R, 1407F, 1497R and 23S30R) on a Sanger Sequencer (3730 DNA Analyzer) at the GIGA sequencing facility (http://www.giga.ulg.ac.be). Individual sequences were trimmed and aligned using Geneious R7.1.7 and compared to the GenBank database using BLAST. To build phylogenetic trees, three most closely related strains and uncultured sequences, respectively, were retrieved by SeqMatch of the Ribosomal Database Project (http://rdp. cme.msu.edu/seqmatch/seqmatch_intro.jsp). The sequences from Arp et al. [17], Cousin and Stackebrandt [35] and Brinkmann et al. [36] were added when they belonged to the clade B of the latter authors, where our sequences are positioned, plus two thin Oscillatoriales. The sequence of Leptolyngbya boryana PCC73110 was selected as outgroup. The sequences were aligned with BioEdit [48]. A first analysis was performed on several long sequences of $1419 \mathrm{bp}$. However, the tufa sequences from Germany [35], even though closely related to ours, were too short and a second alignment was made with $454 \mathrm{bp}$ to include them. The pairwise sequence differences were calculated with MEGA6 [49]. In both cases, Neighbor-joining trees were built with Treecon [50], with the Kimura correction for multiple mutations (selected by MEGA6), indels not taken into account and a bootstrap analysis involving 500 re-samplings. For the ITS sequences, a BLAST analysis was used to find the related sequences, but only the sequences that could be meaningfully aligned were kept in the alignment. Phylogenetic analysis of the ITS sequences was done by the same methods as the $16 \mathrm{~S}$ rRNA sequence analysis, with the exception that the Jukes and Cantor model [51] was used for nucleotide substitutions.

\section{Results}

\section{Hydrology and Water Chemistry}

The deposits of ambient temperature travertine or calcareous tufa form a series of cascades in the Hoyoux River and its Triffoy tributary (Fig. 1). Data collected in February corresponded to high water (HW) and, in October 2014, to 
Table 1 Water chemistry in the Hoyoux and Triffoy rivers in February and October 2014

\begin{tabular}{|c|c|c|c|c|}
\hline & \multicolumn{2}{|l|}{ Hoyoux } & \multicolumn{2}{|l|}{ Triffoy } \\
\hline & February & October & February & October \\
\hline Water temperature $\left({ }^{\circ} \mathrm{C}\right)$ & $5.9 \pm 0.3$ & $10.0 \pm 0.1$ & $6.5 \pm 0.4$ & $9.7 \pm 0.0$ \\
\hline Specific conductivity $\left(\mu \mathrm{S} \mathrm{cm}^{-1}\right)$ & $602 \pm 3$ & $608 \pm 1$ & $644 \pm 1$ & $646 \pm 3$ \\
\hline Total alkalinity $\left(\mu \mathrm{mol} \mathrm{L}{ }^{-1}\right)$ & $4998 \pm 8$ & $4944 \pm 217$ & $5127 \pm 115$ & $4120 \pm 559$ \\
\hline $\mathrm{NO}_{3}^{-}\left(\mu \mathrm{mol} \mathrm{L}{ }^{-1}\right)$ & $429 \pm 6$ & $368 \pm 1$ & $436 \pm 1$ & $372 \pm 12$ \\
\hline $\mathrm{NH}_{4}^{+}\left(\mu \mathrm{mol} \mathrm{L}{ }^{-1}\right)$ & $2.9 \pm 1.2$ & $2.4 \pm 0.2$ & $2.8 \pm 0.8$ & $2.3 \pm 0.4$ \\
\hline $\operatorname{SRP}\left(\mu \mathrm{mol} \mathrm{L}^{-1}\right)$ & $1.2 \pm 0.1$ & $1.8 \pm 0.1$ & $0.7 \pm 0.1$ & $0.9 \pm 0.0$ \\
\hline $\mathrm{pH}$ & $8.29 \pm 0.20$ & $8.15 \pm 0.05$ & $8.48 \pm 0.01$ & $8.01 \pm 0.25$ \\
\hline $\mathrm{O}_{2}(\%)$ & $95.3 \pm 5.7$ & $100.0 \pm 3.5$ & $101.0 \pm 0.4$ & $100.2 \pm 0.7$ \\
\hline $\mathrm{O}_{2}\left(\mu \mathrm{mol} \mathrm{L}^{-1}\right)$ & $363 \pm 24$ & $348 \pm 11$ & $378 \pm 1$ & $353 \pm 2$ \\
\hline $\mathrm{pCO}_{2}(\mathrm{ppm})$ & $1348 \pm 195$ & $1964 \pm 278$ & $1097 \pm 312$ & $1264 \pm 272$ \\
\hline $\mathrm{CH}_{4}\left(\mathrm{nmol} \mathrm{L}^{-1}\right)$ & $88 \pm 45$ & $153 \pm 113$ & $40 \pm 18$ & $44 \pm 23$ \\
\hline $\mathrm{N}_{2} \mathrm{O}\left(\mathrm{nmol} \mathrm{L}^{-1}\right)$ & $70 \pm 48$ & $66 \pm 31$ & $13 \pm 6$ & $15 \pm 5$ \\
\hline
\end{tabular}

low water (LW) periods, with water discharges of 1.1 and $0.5 \mathrm{~m}^{3} \mathrm{~s}^{-1}$, respectively (for the Hoyoux between Point de Bonne and Ferme de Barse). The water chemistry was analysed for both Hoyoux River and Triffoy tributary (Table 1), but no hydrological data were collected for the latter. Both waters are characterised by relatively high $\mathrm{pH}$ and total alkalinity with oxygen concentrations close to the atmospheric equilibrium. The $\mathrm{pCO}_{2}$ values were significantly above the atmospheric value (400 ppm) throughout the studied river flow; however, the most significant small-scale decreases were caused by degassing at the turbulent passages and water falls (Fig. 2; Supplementary Fig. 1), which are also responsible for the overall longitudinal $\mathrm{pCO}_{2}$ decreases and the associated carbonate precipitation. The waters of both rivers were high in $\mathrm{NO}_{3}{ }^{-}$concentrations but comparatively low in $\mathrm{NH}_{4}{ }^{+}$and SRP concentrations; they were supersaturated with respect to $\mathrm{CO}_{2}, \mathrm{CH}_{4}$ and $\mathrm{N}_{2} \mathrm{O}$ (Table 1). In February and October 2014, a decreasing trend in $\mathrm{pCO}_{2}, \mathrm{CH}_{4}$ and $\mathrm{N}_{2} \mathrm{O}$ was observed along the Hoyoux river flow (Supplementary Fig. 1).

\section{Physical Properties of the Calcareous Crusts}

The external shape of the deposit and its internal texture varied in different parts of the system of travertine barriers and waterfalls (Fig. 3a). Three types of samples with different calcification patterns were recognised in the field as subjects for this study (Supplementary Fig. 2). In the nearly laminar flow over the tops of travertine barriers (Fig. 3b), we observed poorly calcified flat mats, comprised of aquatic mosses and moss protonemata, covered by uncalcified or weakly calcified red and green algae (Fig. 3c); in the moderate flow between barriers and cascades, we collected oncoids and submersed encrusted wooden branches (Fig 3a and insert). The oncoids were coated by porous carbonate crust of velvet-like consistency and with small granular protrusions (Fig. 3d); in cascades, on sites receiving high water impact (Fig. 3e), we encountered compact crusts with smooth surface of shiny appearance, bluegreen to steel-blue in colour, which covered the travertine surface or encrusted branches that were trapped there (Fig. 3f).

\section{Degassing in Hoyoux travertine system}

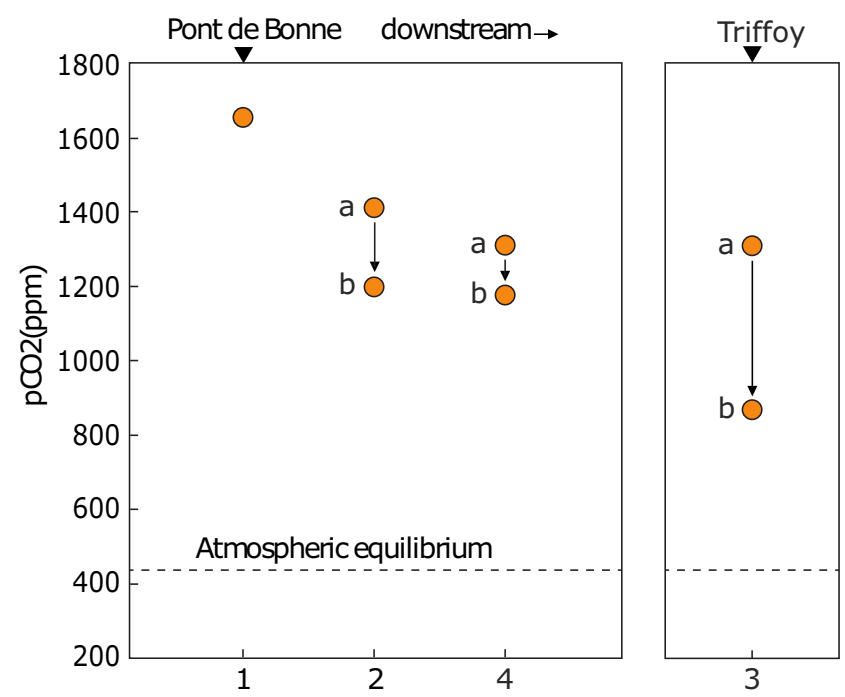

Fig. 2 Distribution of $\mathrm{CO}_{2}$ partial pressure $\left(\mathrm{pCO}_{2}, \mathrm{ppm}\right)$ before and after a series of travertine cascades (sites 2-4), illustrating the high carbon dioxide levels responsible for carbonate supersaturation of the water and degassing as condition for carbonate precipitation. Note the $\mathrm{pCO}_{2}$ measured consistently above the atmospheric equilibrium level, with significant drops occurring at the positions of travertine cascades 
Fig. 3 Travertines of the Hoyoux river system, Belgium. a View of a series of travertine barriers across the river with cascades (see Fig. 1, collection site 2) and moderate water flow (downstream of cascade) Insert: oncoids in the moderate stream (indicated by arrow) between barriers with the encrusted twig (right, $5 \mathrm{~cm}$ long). b Arched barrier with smooth overflow. c Poorly calcified mosses and algae from the overflow in (b). d Oncoids and encrusted wooden branches from moderate water flow between the barriers. $\mathbf{e}$ Waterfalls with high impact habitats. f Compact encrustation with hard steel-blue surface from high water impact habitats in (e)
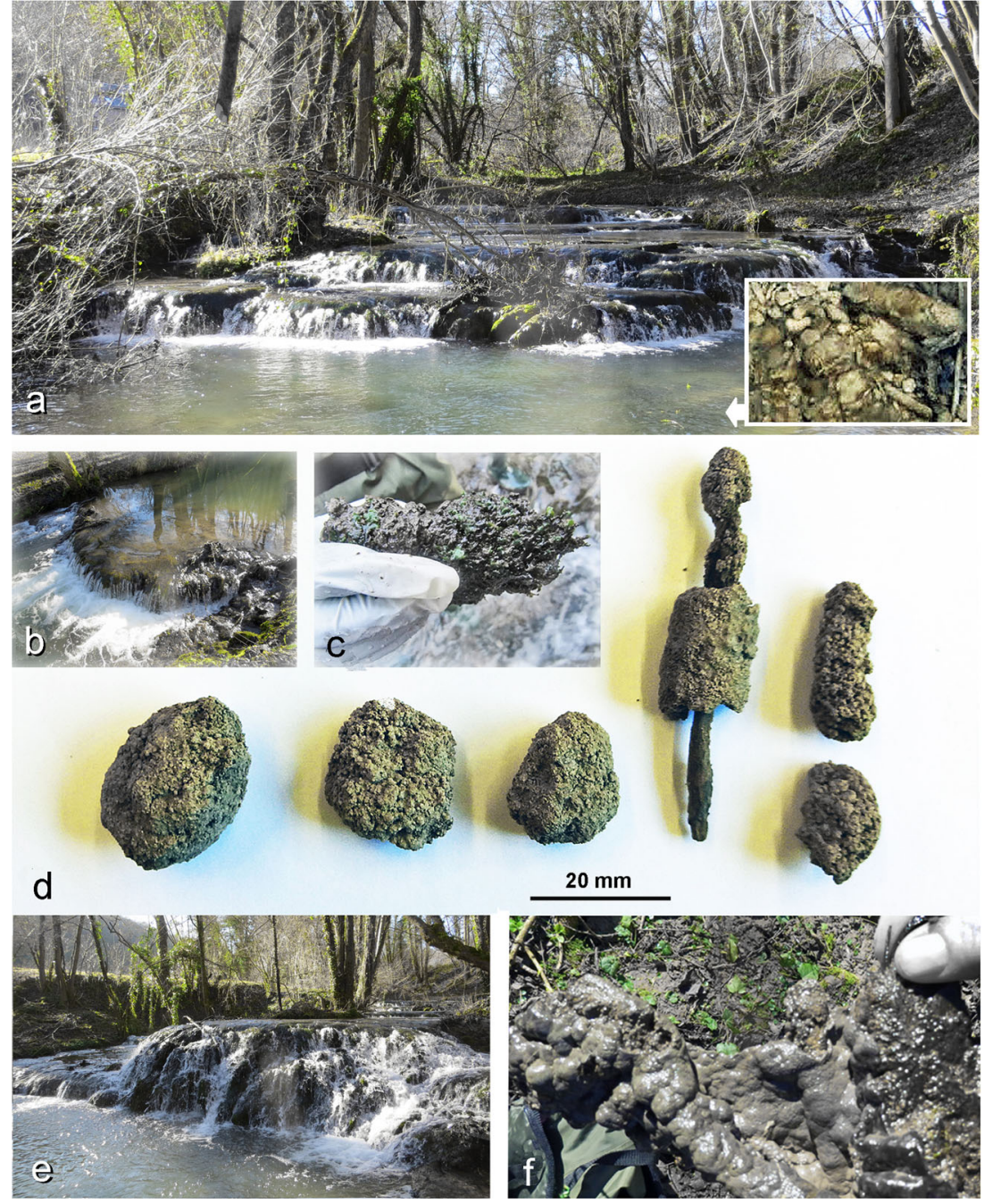

In the first sample type, it was possible to observe the partial stages of calcification, whereas the carbonate structure in oncoids and tightly compacted crusts in cascades was complete and well organised. The porous velvet-like crust that was coating the surfaces of oncoids (Fig. 4a) and encrusted branches under moderate flow conditions was constructed of calcified tubules that were like tiny needles (Fig. 4b), orientated in different directions and interconnected, thus leaving pore space between them. These calcareous tubules were formed by calcification of extracellular sheaths (EPS) of filamentous cyanobacteria. The tubules became frequently fused into clusters and granular protrusions, fractions of a millimetre in size, when fortified by inter-tubular cement (Fig. 4c, d). In contrast, the smooth compact crusts (Fig. 3f) under high water impact were composed of densely arranged calcareous tubules of the same size as those in the velvet crust but arranged parallel to one another and oriented perpendicular to the crust surface. Such dense crusts often provided a firm coating over porous deposits on the ground (Fig. 4e) or encrusted branches (Fig. 4f) and are responsible for dense horizons within travertine deposits with stromatolite-type laminations.

\section{Cyanobacteria Associated with the Calcification Front}

All calcified microhabitats of the studied travertine (sites 2, 3 and 4) were dominated by a sheathed filamentous nonheterocystous cyanobacterium, identified by phenotype (morphology and ecology) as Phormidium incrustatum (Nägeli) Gomont (Fig. 5), which is characterised by straight trichomes (one trichome per filament) inside thin but firm and distinctive individual sheaths (Fig. 5b, arrow). The trichomes were unconstricted at the cross walls, sometimes with granulations along them, shortly attenuated at the tips and, when fully differentiated, ending with a flatconical terminal cell, with thickened outer wall. The cells were $5.92 \pm 0.41$ (34) $\mu \mathrm{m}$ wide, shorter than wide, $1.41 \pm 0.35$ (31) $\mu \mathrm{m}$ long, blue-green to olive-green in colour (Fig. 5a) when grown in their natural environment 

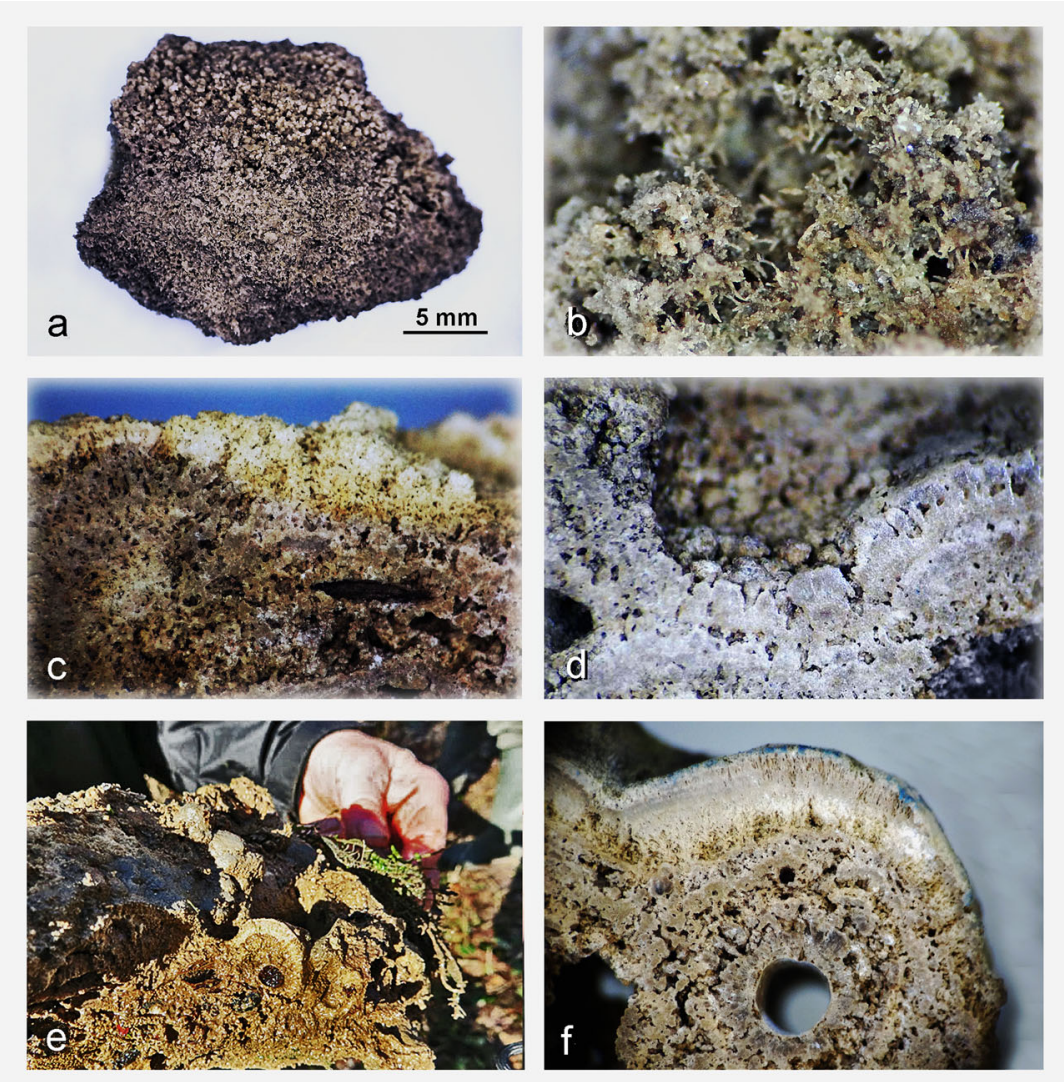

Fig. 4 Cyanobacterial calcareous crusts. a Oncoid covered by two types of encrustation: nodular (above) and porous velvety (below). b Close-up view of the velvety crust, a porous spatial network of irregularly oriented calcareous tubules produced by Phormidium incrustatum. c Predominantly upward diverging clusters of Phormidium tubules generating a nodular surface. d Section perpendicular to a consolidated

on fully illuminated surfaces, but purple to red when grown deeper in the crust or on shaded sites (Fig. 5b). When transferred on agar surface, the Phormidium trichomes reacted with intense gliding movement and showed an increased variability in colour and diameter (Fig. 5c). Several uni-cyanobacterial strains were isolated from single trichomes and maintained in culture. To test for the ability for complementary chromatic acclimation [52], two subcultures (Isolate 5 and 6) were grown separately under green and red light (using differently coloured plastic filters; adapted from Tandeau de Marsac [53]). The results were positive, showing a predominance of the blue-green phycocyanobilin pigmentation (Fig. 5d) when grown under red light and a change in coloration to purple when grown under green light (Fig. 5e), probably due to predominance of phycoerythrobilin pigment.

The porosity of the carbonate crust, especially in the weakly calcified almost laminar overflow over the barriers, promoted settlement and/or entrapment of other eukaryotic and prokaryotic microorganisms, present mostly nodular crust covering an oncoid. e A fractured travertine crust showing the transition from a porous velvety to a compact crust (lighter colour) forming a hard top surface. $\mathbf{f}$ Concentric changes in encrustation shown on the section of an encrusted twig, collected from a waterfall receiving high water impact. The scale bar in (a) is $5 \mathrm{~mm}$ for (a) and (f) and $100 \mu \mathrm{m}$ for $(\mathbf{b}),(\mathbf{c})$ and $(\mathbf{d})$

in small populations (Supplementary Fig. 3). Several eukaryotic algae have been observed in the crust, notably the large filaments without cross walls of the yellowgreen alga Vaucheria sp. often associated with diatoms (Supplementary Fig. 3a, b also in Figs. 7c and 11a) and with the freshwater rhodophyte Batrachospermum sp. in a Chantransia growth stage (Supplementary Fig. 3c). Among eukaryotic organotrophs, a large oomycete has been found trapped and cemented while responding by massive release of oospores, many of them germinating (Supplementary Fig. 3d). The accompanying cyanobacteria include pleurocapsalean taxa characterised by multiple fission and release of small reproductive cells or baeocytes (Supplementary Fig. 3e), including euendolithic Hyella fontana Huber et Jadin, which may have been penetrating the already consolidated carbonate parts of the crust (Supplementary Fig. 3f). Among filamentous cyanobacteria, we observed scattered populations of a Lyngbya sp., with filaments significantly narrower than the dominant $P$. incrustatum (cells $3.2-3.5 \mu \mathrm{m}$ wide 

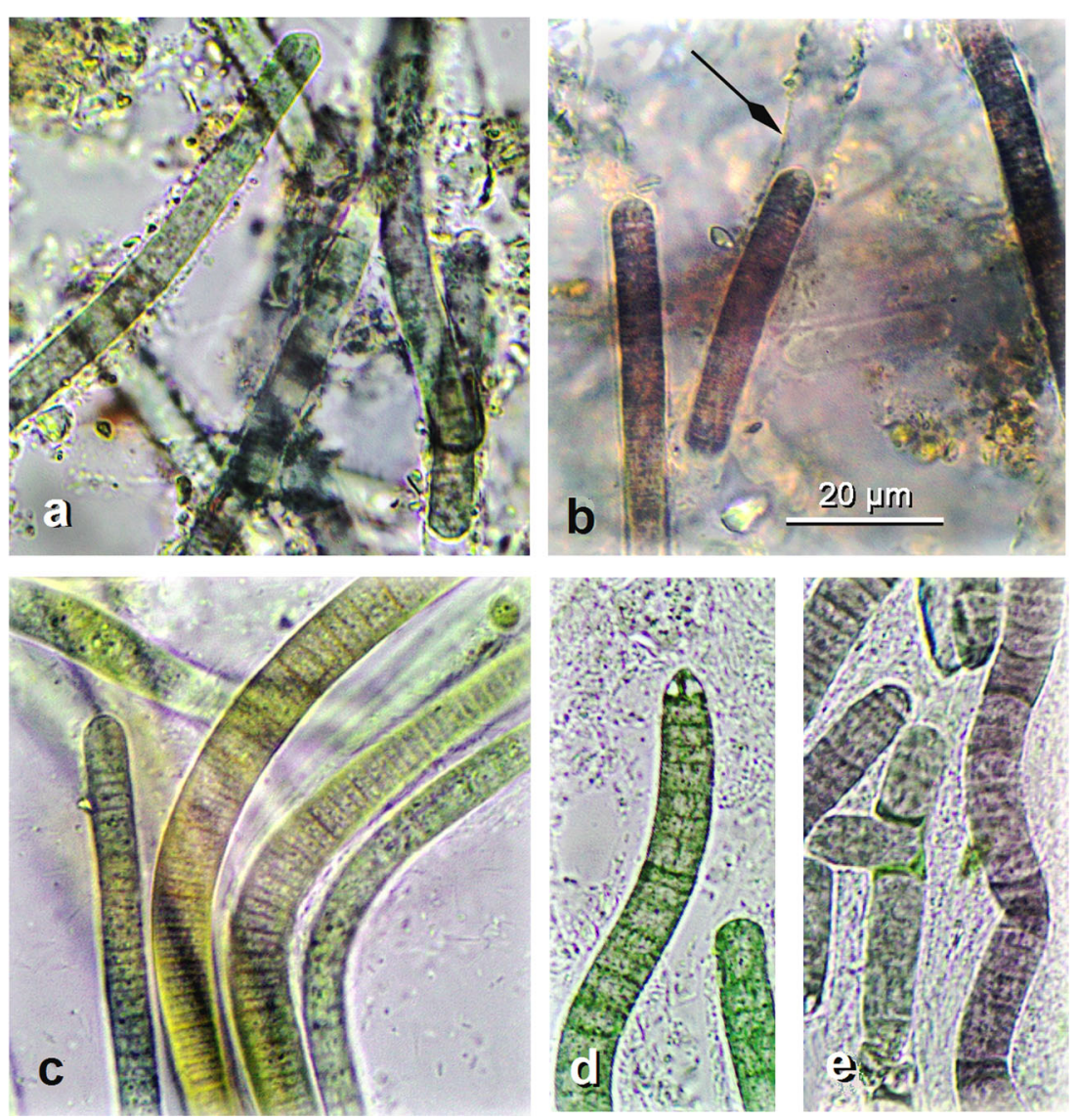

Fig. 5 Cyanobacterial Phormidium strains detected in the Hoyoux travertine including Phormidium incrustatum (Nägeli) Gomont, the main architect in the formation of Hoyoux travertines. a Filaments extracted from the illuminated surfaces of travertine oncoids after dissolving the carbonate. b Filaments extracted from the shaded areas of travertine inside the crust. Note the difference in cell pigments. c Trichomes of varying diameters and pigmentation, isolated in raw

and 1.0-1.2 $\mu \mathrm{m}$ long, Supplementary Fig. $3 \mathrm{~g}$ ), the heterocystous cyanobacterium Calothrix sp. accompanied by the pleurocapsalean Xenococcus sp. and densely bent and coiled Leptolyngbya sp. with mildly constricted but conspicuous cross walls (cells $1.1-1.4 \mu \mathrm{m}$ wide and 2.5$3.5 \mu \mathrm{m}$ long). All these cyanobacteria produced EPS sheaths and envelopes, including some chroococcalean cyanobacteria classified within the genus Aphanocapsa that occurred in small colonies interspersed in the crust. Some of these accompanying taxa may have been trapped together with the leaf detritus; whether they can become permanently established in the crust is not certain.

\section{Phylogenetic Relationship among Travertine-Forming Microorganisms}

In order to identify the genetic signature of the most prevalent microorganism in the system, the 16S rRNA gene and the ITS fragments from five samples, MOD-14, MOD-14s (surface), culture, actively gliding on the agar surface. d Uni-cyanobacterial culture (Isolate 6) grown under red-filtered light, as part of the complementary chromatic acclimation (CCA) test: the pigmentation enriched in phycocyanobilin. (e) Uni-cyanobacterial culture (Isolate 5) grown under green-filtered light, part of the same CCA testing as in (d): cultures grown under green light filter show pigment shift toward predominance of phycoerythrobilin

MOD-15, MOD-15s (surface) and MOD 21, were directly amplified by PCR from the environment (site 3 and site 2 in June, site 3 in August) and sequenced. All sequences obtained are listed in Supplementary Table 1, together with their origin, GenBank submission numbers and BLAST hits. The sequence MOD 15 was discarded from further analysis because of bad quality. The amplified 16S rRNA gene sequences MOD 14, MOD 14s and MOD 21 are almost identical and show only $1 \mathrm{bp}$ difference to each other, in addition to four ambiguities with MOD 15s. This finding suggests that a single species or a cluster of very closely related genotypes prevailed during the spring and summer season in at least two locations: Triffoy and Moulin de Roiseux on Hoyoux River.

When subjected to a BLAST search using the GenBank database (Supplementary Table 1), all the 16S rRNA sequences obtained directly from the environmental samples corresponded with $>99.2 \%$ (1347 bp) and 100\% (656 bp) similarity to the uncultured cyanobacterium clones WB18.8 (GenBank accession no. GQ324964) from a German tufa 
system [17, 35]. The habitats in the German study, the Westerhöfer creek in the Harz Mountains, are very similar to those in the Hoyoux system, with high concentrations of calcium and magnesium in the water and formation of tufa cascades associated with microbial calcification. The detection of the same dominant organism in both systems, now supported by almost identical 16S rRNA sequences, suggests that the same cyanobacterial taxon might dominate several Middle European travertine systems.

Seven distinct Phormidium-type uni-cyanobacterial strains have been obtained in the process of isolating the dominant microorganism of the Hoyoux travertines in culture (Supplementary Table 1). The 16S rRNA genes shared a pairwise identity of $98.2 \%$ between these seven isolates, showing a larger diversity than the field sample sequences. The 1403-bp fragment of the 16S rRNA gene of unicyanobacterial Isolate 8 was found to be $99.8 \%$ (BLAST) similar to the uncultured cyanobacterial clone WB18.8 from the German tufa system mentioned above (Supplementary Table 1). Moreover, the shorter V3-V4 region of the $16 \mathrm{~S}$ rRNA gene of Isolate 8 was $100 \%$ identical to the sequences found in the spring and summer environmental samples of the Triffoy (site 3) and the Hoyoux (site 2). This means that Isolate 8 is identical to and representative of the dominant species in the two sampled travertine systems. Since Isolate 8 was generated from a sample taken in February, whereas the direct environmental sequences were obtained in June and August (see above), it can be assumed that the same organism is predominant at these sites throughout the year. Its phenotypic properties (see also Pentecost [54]) correspond to P. incrustatum (Nägeli) Gomont.

The genetic relationship of the seven isolated unicyanobacterial strains to the amplified environmental sequences as well as to reference strains from public databases is presented in phylogenetic trees based on long and short $16 \mathrm{~S}$ rRNA gene sequences (Fig. 6 and Supplementary Fig. 4). The shorter alignment was necessary to include short sequences from German travertines. The scales of the trees are very small, and thus all the groups displayed are very similar to each other. Even so, the trees clearly show that the $16 \mathrm{~S}$ rRNA gene sequence of Isolate 8 is most closely related to those sequences obtained directly from the environmental material of the Hoyoux travertine system (MODs 14, 14s and 21) as well as to the uncultured WB18.8, CL2.C6, BF.S97 and BF.S143 from the German tufa system. Less closely related, but still in the same cluster, are other environmental sequences (MOD 15 because of one substitution and a few ambiguities) as well as an uncultured bacterium strain Llo 001 (GenBank accession no. FR667299) from epilithic biofilms in a mountain lake in Spain [55] and a strain from the epipelon of a Czech lake [56] identified as Phormidium autumnale.

More variation than in the 16S rRNA gene was observed in the ITS sequences (Supplementary Table 1 and
Supplementary Fig. 5). The ITS region is a highly variable genetic spacer between the $16 \mathrm{~S}$ and the $23 \mathrm{~S}$ rRNA genes. The ITS regions of the environmental samples were $94.2 \%$ similar to each other, suggesting that slightly different genotypes are present in the travertine system, probably within the same morphotype. The ITS sequences of the isolates were also highly variable, supporting this hypothesis.

\section{Relationship between Cyanobacteria and Carbonate Deposits}

The filamentous cyanobacterium, identified as $P$. incrustatum, was found to predominate in all carbonate-encrusted deposits in the travertines under study. The observed different surface textures of the carbonate crust appear to be due to cyanobacterial growth response to water flow and impact. The porous velvet crust with divergent tubules was found in sections with slow to moderate water flow, where the cyanobacterial filaments were able to grow in any direction. In contrast, in areas of high water impact in cascades, where the crusts are compact and have highest increment rates, the cyanobacterial filaments were directed outward and perpendicular to the crust surface.

Individual filaments observed in the loose velvet-like coatings under moderate flow conditions form tubular, externally conical calcareous encrustations around their sheaths (Fig. 7a). The tips of calcified tubules are "plugged" by trichomes (Fig. 7a, insert), which move in and out leaving the opening free of sediment while the carbonate precipitation in the surrounding ambient continues to add cement between the tubules (Fig. 7b). BSE-SEM images of polished sections of resin-embedded cyanobacteria in their mineral context show carbonate crystal nucleation to be initiated within the EPS sheath (Fig. 7c, arrows) from where the crystals expand outward (Fig. 7d). The calcification starts in the EPS at the filament tip, frequently forming a thin calcareous collar, but always leaving the smooth and uncalcified interior of the sheath (Fig. 7e). The external calcification of tubules continues in the surrounding environment and fuses the tubules together (carbonate cementation), a process that forms nodules (Fig. 4c, d) and ultimately solid carbonate tufa, while leaving the interiors of the tubules empty. The intact sheaths lining the interior of tubules are presented by SEM of a fractured travertine rock (Fig. 7f). The pores left between filaments are sites of independent calcium carbonate precipitation also forming rhombohedral calcite clusters (Fig. $7 \mathrm{~g}$ ). The relations between $P$. incrustatum trichomes and carbonate deposit on the hardcrust surfaces from the cascades are shown in the SEM images of critical-point-dried specimens as overview (Fig. 7h) and in detail (Fig. 7i).

The close relationship between cyanobacteria and carbonate precipitate was further studied by BSE-SEM imaging of resin-embedded travertine samples of 


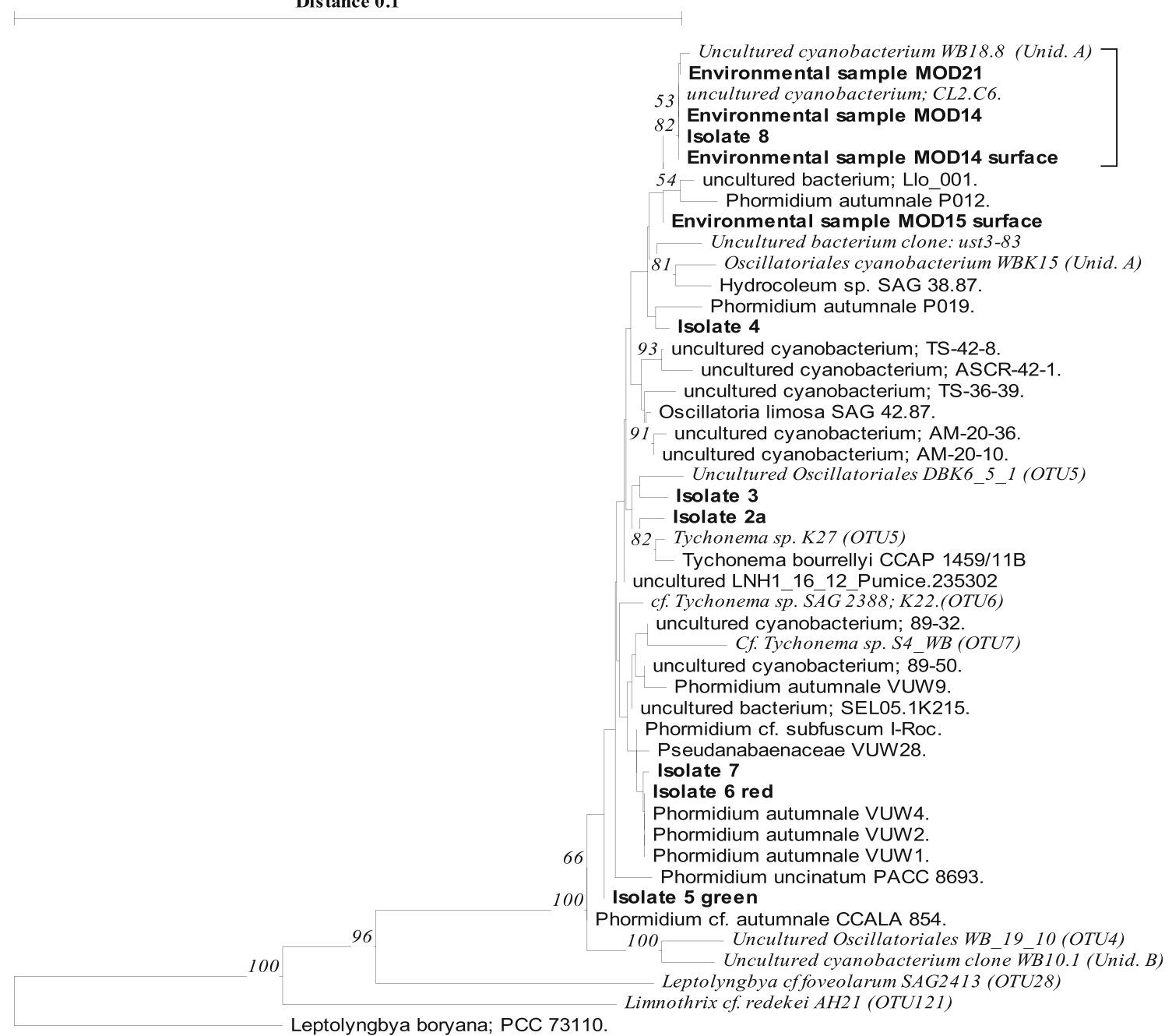

Fig. 6 Neighbor-joining tree based on 16S rRNA gene sequences (1418 bp) of environmental sequences obtained directly from travertine samples, of isolates obtained from travertine material and from the reference strains from public databases, including uncultured sequences. The distance matrix was corrected by the Kimura equation and indels were not taken into account. A total of 500 resampled trees were calculated for the bootstrap analysis, and the values above $50 \%$ are indicated in front of the corresponding nodes. The Hoyoux sequences are in bold and the travertine and tufa sequences from elsewhere are printed in italics. The OTU numbers are taken from Brinkmann et al. [36] and the 'Unid.' number from Arp et al. [17]

cross walls, enhanced due to osmium and uranium contrast as well as the thickening of the external wall of the apical cell (calyptra ?, white arrow). The x-ray elemental analyses and mapping (Fig. 8d) confirmed calcite mineralogy of the precipitates, the osmium and uranium staining of the trichomes and identified traces of $\mathrm{Si}$ in the Phormidium's EPS sheath (Supplementary Fig. 4). The element analysis also confirmed the presence of silica in trapped diatom frustules and clay particles. The relations between Phormidium tubules and carbonate are presented in a section through the centre of an oncoid (Fig. 8e) showing no carbonate precipitation inside intact tubules. The same can be followed toward the oncoid surface (Fig. 8f, g). However, in oncoids eroded while rolling in the currents, the calcareous (Fig. 8c) shows the cyanophycine granules along the 

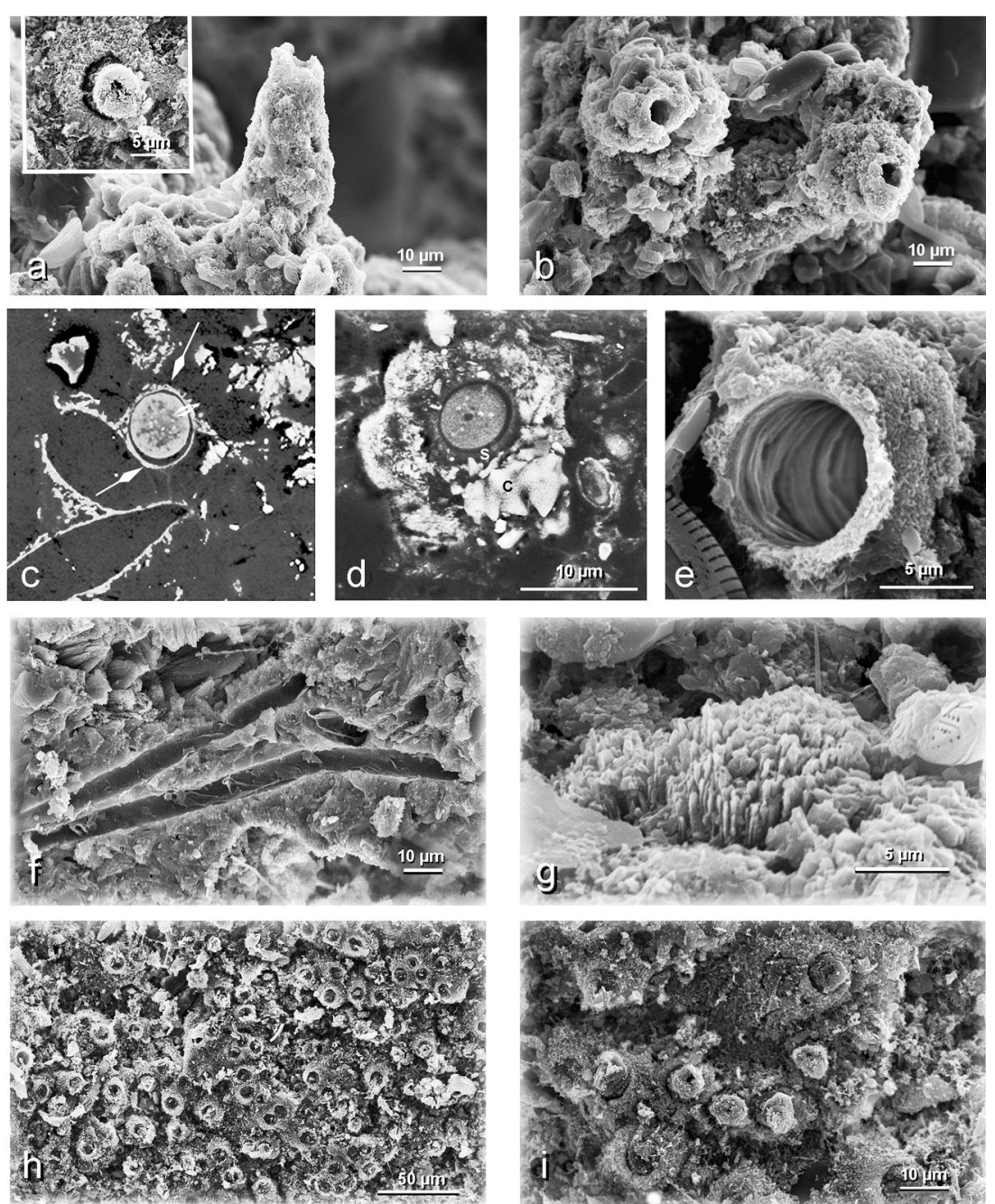

Fig. 7 Calcified structures associated with Phormidium incrustatum. a Conical calcareous tubule produced by Phormidium filament in side view. Insert: Front view of the opening of calcareous tubule with the exiting trichome. Note the fine microcrystalline deposit on the margin of the EPS sheath surrounding the trichome. $\mathbf{b}$ Relief formed by several externally cemented calcareous tubules. c Carbonate crystal initiation (nucleation, arrows) within the sheath close to the filament tip. d Filament in cross-section in the middle part of the tubule, showing radial growth of carbonate $(C)$ from the sheath surface $(S)$ outward. e View of the tip of calcified Phormidium sheath in perspective; note the

Phormidium tubules are broken and exposed to the environmental water so that the carbonate precipitation takes place inside the tubules as well (Fig. 8h).

\section{Progression of the Calcification and Early Diagenesis}

The calcified wooden branches and twigs incorporated in travertine permit the analysis of relatively recent changes in travertine deposition and reveal the onset of early diagenetic changes. In cross-sections through such deposits, it was possible to observe a pattern of zones of different encrustation density, forming textural layers documenting time-bound changes in the actively of growing surfaces, possibly related outward growth of calcite crystals and smoothness of the interior of the tubule. A trapped diatom frustule is at lower left. f Fractured consolidated travertine deposit with tubules nearly in longitudinal section; note the sheath layer lining the lumen of the tubules. $\mathbf{g}$ Group of rhombohedral calcites precipitated in travertine pores independent of Phormidium sheath. h Planar overview of the hard travertine surface exposed to water impact in the waterfall showing the tips of Phormidium tubules (compare Fig. 3f). i Detail of (h) with several trichomes exiting their tubules. a, b, e, f, g Direct SEM; c, d SEM with BSE (backscattered electronic images); a -insert, h, i SEM of critical-point-dried samples

to the environmental conditions (Fig. 9). The same profiles may also reveal early diagenetic alteration of travertine deposits.

Each of the encrusted twigs presented in crosssection showed an external, most recently formed zone of dense carbonate deposit that incorporated void, outward radiating Phormidium tubules (Fig. 9a). In the overview of a section (Fig. 9b), this external compact layer (1) includes the surface of the deposit, growing at the time of collection (Fig. 9c). This layer is underlain by a porous travertine layer (2), composed of loosely arranged tubules, similar to the crust observed on oncoids, but less clearly outlined (Fig. 9d). The compact 

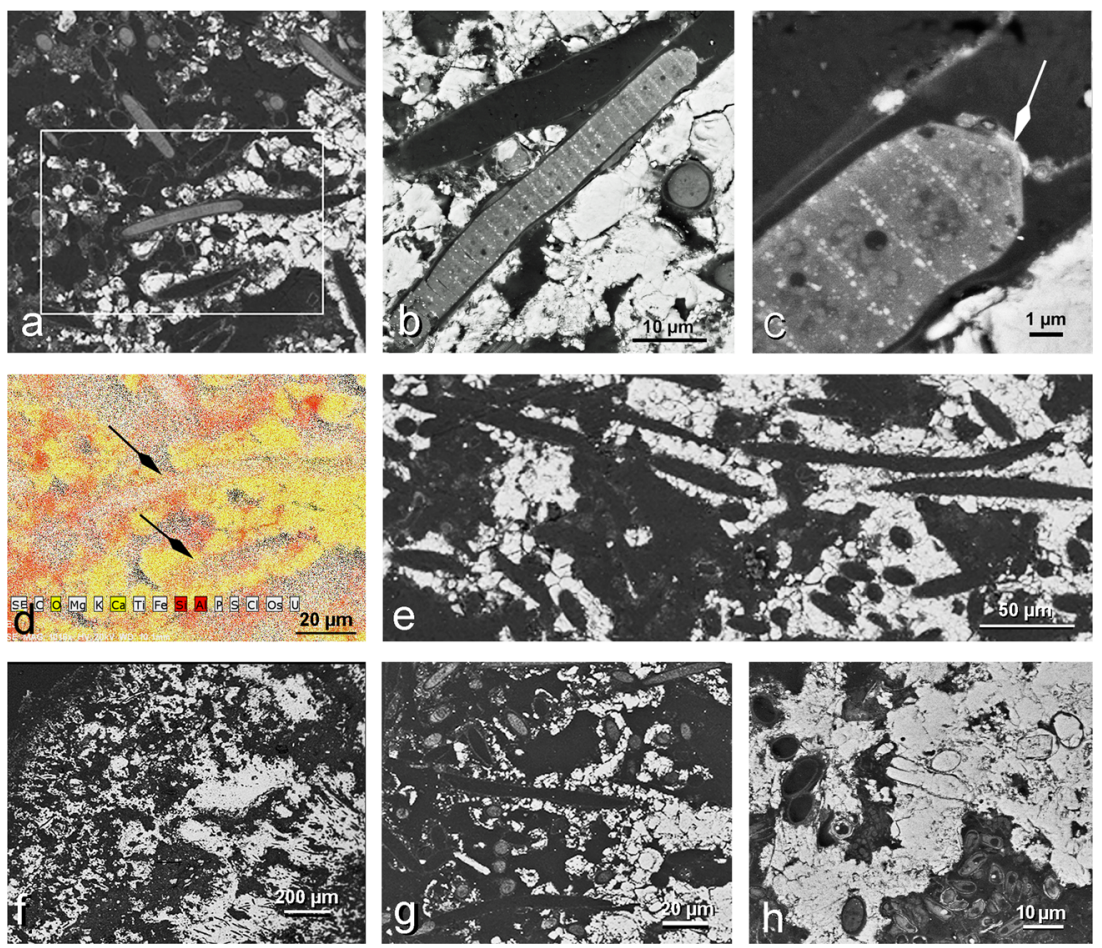

Fig. 8 Relations between Phormidium incrustatum and carbonate deposition. a Section perpendicular to the substrate surface showing three Phormidium trichomes emerging from their sheaths and calcareous tubules. The white frame designates the area of the elemental $\mathrm{x}$-ray mapping in (d). b Phormidium filament in its carbonate context. c Detail, note the cyanophycine granules along the cross walls, the narrowed (calyptrate) terminal cell, marked by white arrow and the two-layered EPS sheath with calcite granules included. d Elemental xray mapping of the frame outlined in (a). Silicon and aluminium (both marked $r e d$ ) are present in diatom frustules and clay particles trapped between Ca-carbonate grains (in yellow), but it also labels the EPS sheaths of the cyanobacteria (arrows). e Phormidium tubules in the interior of the dense carbonate crust remain hollow as long as the tube interior is not accessed by carbonate-supersaturated environmental water. f Section through an oncoid showing an interior calcareous block with hollow tubules (right), a solid block with tubules filled with carbonate (centre) and an active incompletely calcified oncoid surface (left). $\mathbf{g}$ Detail from the intact surface area of the oncoid in (f) (left), with intact tubules. $\mathbf{h}$ Detail of the eroded oncoid with tubule interior filled by carbonate precipitate. All pictures are oriented with the surface of the crust to the left (BSE imaging and $\mathrm{x}$-ray elemental mapping of polished thin sections of samples, stained with $\mathrm{OsO}_{4}$ and uranium acetate) surface layer (Fig. 9a), when viewed in cross-section (Fig. 9e), shows a distinction between calcification that originated from cyanobacterial sheaths around Phormidium trichomes (t) and from inter-tubular cement precipitated independently in the pore spaces $(\mathbf{p})$. An arrow points to that boundary.

The zone immediately surrounding the encrusted twig (layer 3 in Fig. 9b), and therefore the oldest component of the structure, features large calcite crystals (Fig. 9f, g), which also comprise the most compact carbonate zone. The encrusted branch is surrounded by a series of dense outward divergent mineral units, marked by periodic upward convex pseudostromatolite lines (Fig. 9f). The Phormidium tubules, although involved in the original sediment, are here rarely preserved with their lumens partially or completely closed. Their openings can be seen only as exits at the upper surfaces of the crystal units toward the internal pore spaces (Fig. If above). The preserved remains of tubules and the up- and outward diverging orientation (Fig. 9g) identify these calcite units as re-crystallised clusters of the once similarly diverging
Phormidium tubules, marking the onset of early diagenetic alteration.

\section{Raman Microspectroscopy of Travertine}

Samples of loose travertine coatings of oncoids and encrusted branches, and compact deposits exposed to cascade impact were analysed by Raman microspectros copy (Fig. 10) to examine the alteration of the organic structures incorporated in the sediment. Raman analyses were performed along a profile from the active surface to the interior of the carbonate crust that was resin-embedded, sectioned perpendicular to the surface and polished (Fig. 10a). Local accumulation of the UVprotecting pigment, beta-carotene, has been identified along the contact between calcite grains on the edges of a laminated pseudo-stromatolite texture (Fig. 10b). Organic content with still preserved beta-carotene was also recorded in calcified tubules (ca. $2 \mu \mathrm{m}$ in diameter) and a broken tubule likely resembling a collapsed trichome $(<1 \mu \mathrm{m}$ in diameter, Fig. 10c, d). The pigment seemed to be associated with the 

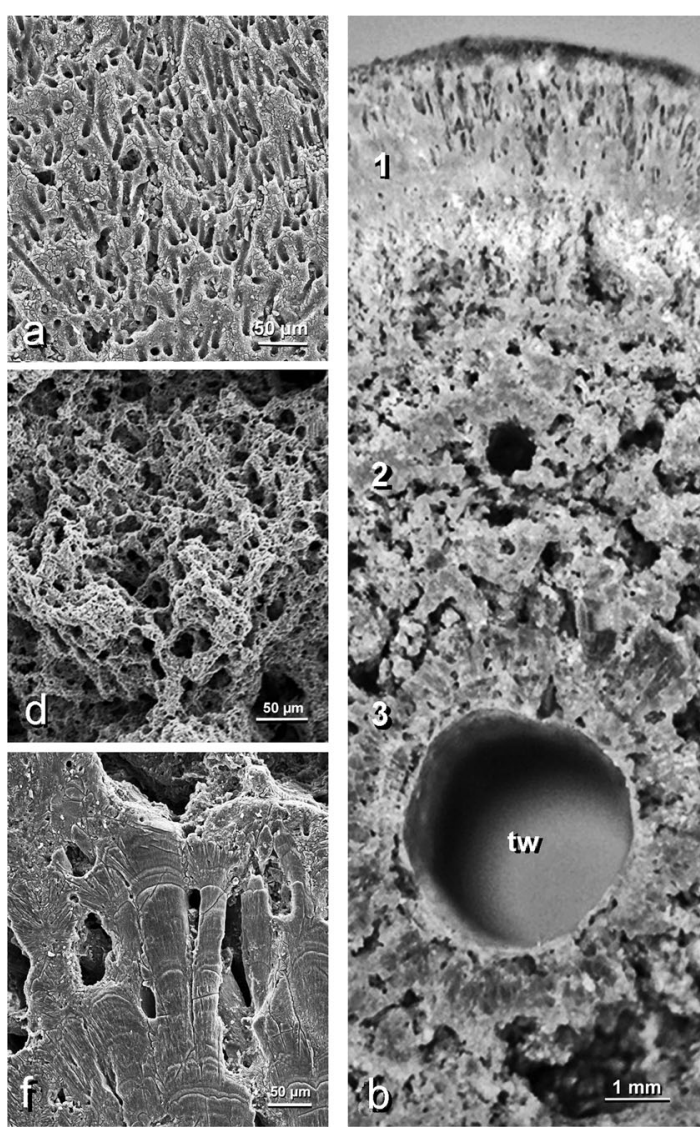

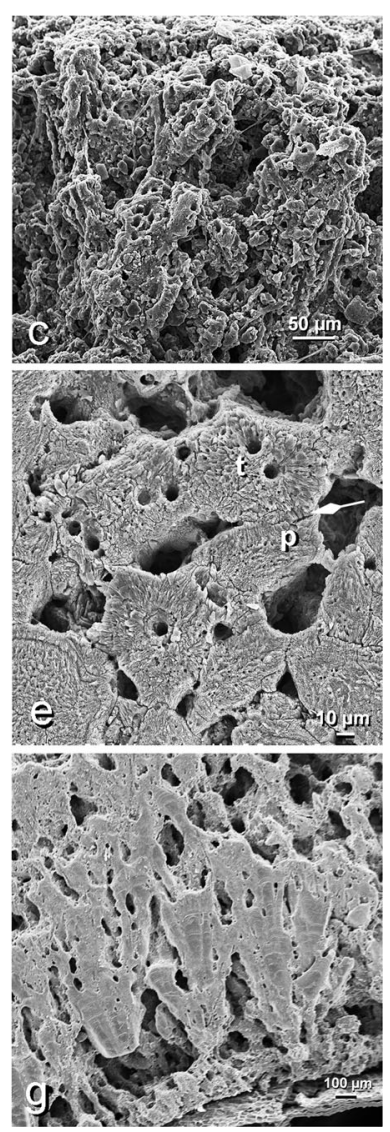

crust (area 2 in b), as observed in moderate water flow. e Cross-section of the compact, high impact crust (area 1 in b), illustrating carbonate deposit around Phormidium tubules $(t)$ and in pores $(p)$ between filament clusters with an arrow pointing to the boundary. f Pseudo-stromatolite-type of lamination in recrystallised parts of the travertine. $g$ Detail of the recrystallised layer of travertine next to the encrusted twig ( $t w$ in $\mathbf{b})$. b Incident light photomicrograph; c, d: SEM of fractured surfaces; $\mathbf{a}, \mathbf{e}, \mathbf{f}, \mathbf{g}$ : SEM of polished petrographic thin sections

dissolution of carbonate, which revealed an accumulated organic matter with the predominance of empty sheaths.

In summary, we observed an evolution of the Raman signal from beta-carotene UV protective pigments preserved in the young travertine crust to unspecific CM signal observed deeper inside and therefore older travertine crust. The preservation of $\mathrm{OM}$ and of calcareous tubules in travertine, on short and long timescales, seems to be poor due to the porous nature of the carbonates prone to oxidation and recrystallisation. However, residual organic matter, usually displaced by recrystallisation, may preserve very locally in a heterogeneous pattern and at a micrometre scale.

\section{Trapping, Binding and Degradation in Travertines}

In all types of deposits, the calcified network of Phormidium sheaths forms an effective filter in which particles suspended 
Fig. 10 Raman spectrum analysis. a Polished cross-section of a laminated travertine crust with the areas of detailed analysis outlined and numbered. b Finely laminated pseudo-stromatolite texture (zone 1 of a). c Preserved tubule (zone 2 of a). d Raman spectra observed for $(\mathbf{b})$ and $(\mathbf{c})$. $\mathrm{e}$ Incorporated 'fossilised' tubules (zone 3 of a). f Raman hyperspectral mapping of the 'fossilised' tubules showing the separation of calcite and carbonaceous matter $(C M)$ in the tubule. g Organic-brown CM accumulations along the contact of some recrystallised cluster of calcite inside the travertine. $\mathbf{h}$ Raman spectra of the CM observed in (f) and (g)
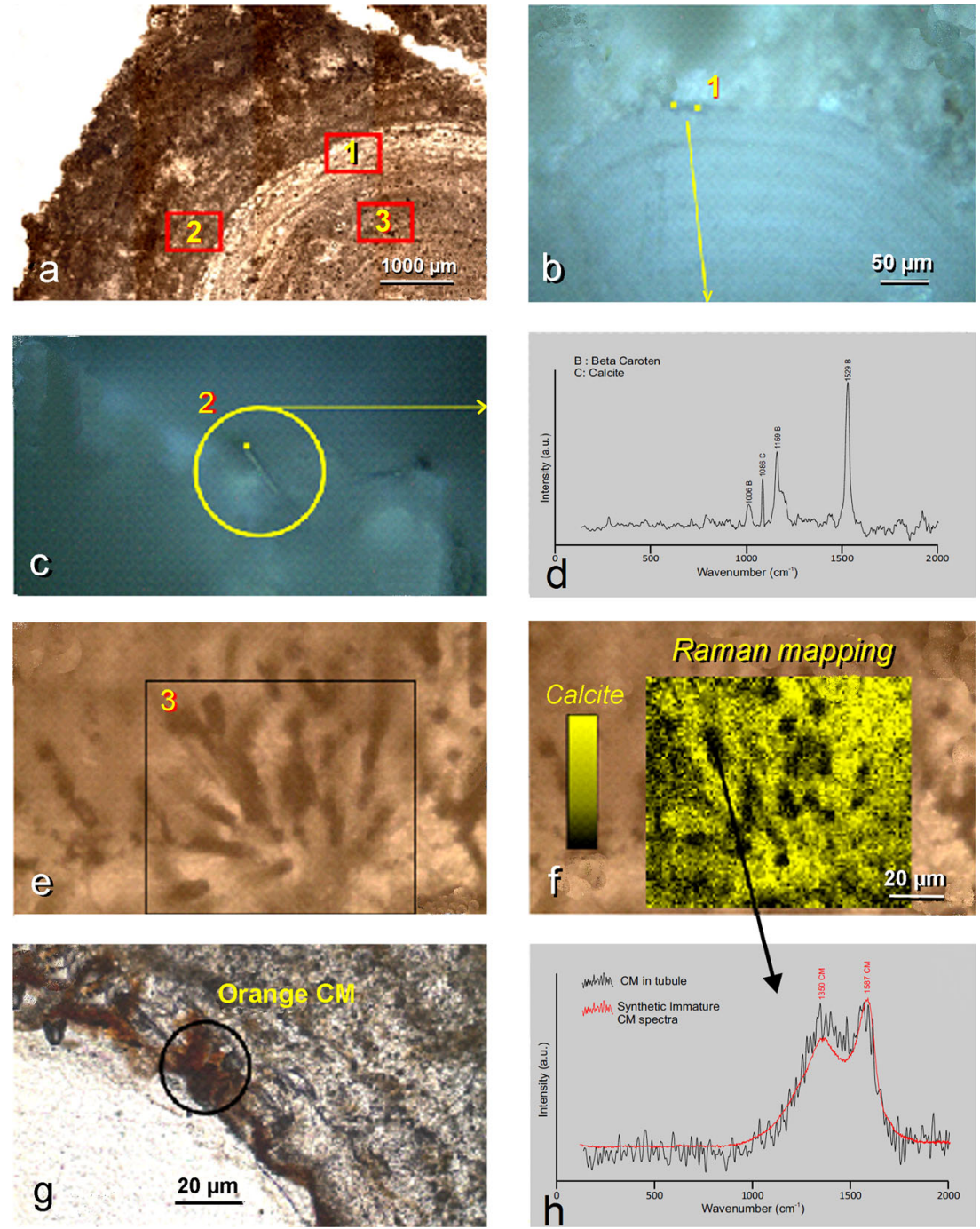

in the water, including planktonic and benthic microorganisms, such as diatoms and other unicellular algae, become trapped, while rapid calcification provides the binding (Fig. 11a, b). This property defines travertines as microbialites or stromatolites. Organotrophic bacteria, which decompose autochthonous as well as the extraneous organic matter, are important in this system, where turbulence and aeration support aerobic decomposition, thereby returning some of the $\mathrm{CO}_{2}$ into the system [57]. Of particular interest are the bacteria associated with degradation of the indigenous primary product of the system, especially of the cells and EPS of cyanobacteria, which remain trapped in the carbonate crust. Dense populations of rod-shaped bacteria were found to fill the space previously occupied by trichome cells (Fig. 11c) and might be involved in the degradation of cyanobacterial organic matter. The entrapped organic compounds are a nutrient source for diverse filamentous and coccoid organotrophic bacteria that were observed by SEM of critical-point-dried preparations, including filamentous bacteria (Fig. 11d) and mostly unknown polar attached rod-shaped bacteria (Fig. 11e, f).

\section{Discussion}

Travertine or calcareous tufa deposits (see Pentecost [54] for definitions) are distributed worldwide [15]. In the studies of complex systems such as the deposition of calcareous tufa or ambient temperature travertines, the questions of biotic versus abiotic factors responsible for the processes involved are commonly asked and discussed [17, 21, 23]. In this context, it is useful to assess the degree of biotic versus abiotic influences separately for different phases of the process, starting with (a) the contributions to water chemistry, then to (b) nucleation and formation of minerals and, finally, (c) to the distribution of sediments in the formation of travertine [57]. By using the 


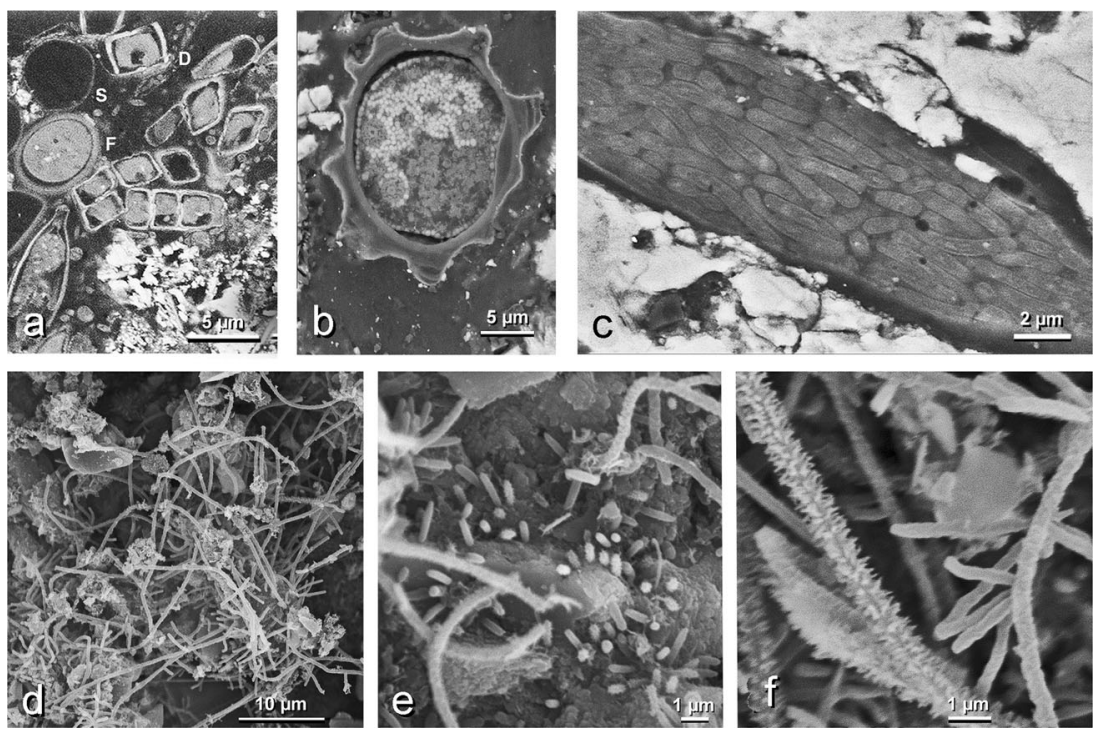

Fig. 11 Microbial assemblages entrapped in travertine. a Entrapped diatom $(D)$ assemblage on poorly calcified oncoid surface close to a filament $(F)$ and an empty sheath $(S)$ of Phormidium (upper left corner). b A chrysophyte cyst entrapped inside an oncoid. c Rodshaped bacteria filling and possibly decomposing a cyanobacterial

example of the Hoyoux river system (Fig. 1), which is one of the 12 known travertine depositing rivers in Belgium [14], a link between the chemical and biological processes involved in travertine deposition could be established in this study.

\section{The Travertine Deposition in Hoyoux River System}

The overabundance of carbonate molecules in the waters under study has two sources: geological availability of calcium and carbonate from limestone and dolomite bedrocks and the biological availability of $\mathrm{CO}_{2}$ from degradation of organic matter in soils of the entire watershed. Thus, the increase of $\mathrm{pCO}_{2}$ above the equilibrium with the atmosphere and the equivalent carbonate supersaturation of the karstic waters are fuelled by a substantial biogenic input [20] and so is, by extension, the degassing of $\mathrm{CO}_{2}$ in the process of re-establishing the equilibrium with the atmosphere. Pentecost [14], who analysed water chemistry in British karstic regions, came to a similar conclusion. The opposite effect is illustrated in the karstic regions of central Italy, where deforestation and loss of soil was thought to be the main reason why the river Volturno does not precipitate carbonate today, while it has produced extensive travertine platforms in the past [33].

The chemical conditions promoting carbonate precipitation that exist along the studied Hoyoux waterways are promoted by $\mathrm{CO}_{2}$-degassing, stimulated in rapids and waterfalls due to the increase in surface-to-volume ratio of the air-water interphase. The $\mathrm{pCO}_{2}$ values in the Hoyoux and the Triffoy $(<2000 \mathrm{ppm})$ are at the lower end of the range of values reported in other meteogene travertines, ranging between 550 and 31,500 ppm [16, 23, 58]. The $\mathrm{pCO}_{2}$ values in the Hoyoux trichome. d Assemblage of organotrophic bacteria around entrapped organic matter in a depression on the surface of an oncoid. e Detailed image of polarly attached organotrophic bacteria. f A different assemblage of organotrophic bacteria. a-c BSE images of polished resin-embedded sections; $\mathbf{d}-\mathbf{f}$ SEM of critical-point-dried samples

and the Triffoy are actually below the average for meteogene travertines of $5200 \mathrm{ppm}$ (distinctly lower than the average of $50,000 \mathrm{ppm}$ for thermogene travertines in hot springs reported by Pentecost [23]). The overall spatial gradient of $\mathrm{pCO}_{2}$ in the Hoyoux was -85 and -183 ppm km$~^{-2}$ in February and October, respectively. These gradients are two orders of magnitude lower than those reported in other travertine systems ranging between about $-10,000$ and $-20,000 \mathrm{ppm} \mathrm{km}^{-2}$ [23]. The distinction, however, may be related to the fact that the other studies of travertines were conducted directly downstream of springs, which was not the case in the present study of Hoyoux. Nevertheless, the level of supersaturation and the measured drop of $\mathrm{pCO}_{2}$ following each set of cascades along the river identified the $\mathrm{CO}_{2}$-degassing as the principal driving force of $\mathrm{CaCO}_{3}$ precipitation with a commensurate loss of carbonate, a part of which may have been incorporated in and contributed to the growth of the carbonate terraces. The relatively high level of nitrate observed in the Hoyoux waterways may indicate eutrophication, which may lower or even inhibit carbonate precipitation and travertine deposition [32].

\section{The Biological Identity of Phormidium incrustatum (Nägeli) Gomont}

The phenotype of the most dominant calcifying organism is a filamentous non-heterocystous cyanobacterium identified as P. incrustatum (Nägeli) Gomont (Fig. 5), which occupies a wide variety of carbonate depositing microenvironments [17, $20,33,54,57]$. The organism was identified by comparing and morphometrically evaluating its phenotypic properties in samples taken from the sites of active carbonate deposition. 
Isolation in culture yielded several morphologically similar and genetically closely related uni-cyanobacterial clones (Fig. $5 \mathrm{c}-\mathrm{e}$ ). Isolate 8 turned out to be genetically identical with the phenotypically dominant populations at two Hoyoux travertine sites (Fig. 6) as well as with clones from travertine deposits from the Westerhöfer creek in the Harz mountains in Germany $[17,35]$. In the latter study, clone WB18.8, which is identical to our dominant sequences, is clustered as 'Unidentified A' and is distant from the suspected P. incrustatum identified and sequenced by Arp et al. [17] as 'Unidentified B' (clone WB10.1) and from the Tychonema strains that these authors also detected. Our isolates 3 and $2 a$ appear to belong to their OTU5, which is related to the type strain of Tychonema bourrellyi CCAP 1459/11 [59]. The phylogenetic tree of Brinkmann et al. [36] did not include the clones identical to our dominant strain, and therefore, we can only guess that it belongs or is closely related to their clade B. This would also correspond to the Tychonemal Phormidium/Microcoleus clade found with a metagenomic study by Schneider et al. [60].

The fact that our culturing, which started with small inoculums placed on standard BG11 [44] 2\% agar, from which individual trichomes were isolated, produced several different, albeit related, uni-cyanobacterial strains raised the question of the identity of these strains with those dominating the natural populations. Past experiences have documented the prevalence of opportunistic organisms favoured by standard culture media at the expense of the field populations that are often adapted to nutrient-deprived extreme life conditions [61] and often do not grow at all in synthetic media [62].

No 16S rRNA gene information of $P$. incrustatum is presently available in public databases, although its morphotype identification and ecology is well established in modern [20, 54] and ancient travertine settings [33]. We used two independent approaches to try to identify the dominant strain in the travertine system: (a) by direct amplification of the 16S rRNA gene fragment from the environment and (b) by sequencing the strains we isolated and cultured from that same environment. We selected the cultured strain that was, by its sequence, closest to the environmental one, which also turned out to be the quasi-identical to the strain WB18.8 from Germany in GenBank. Based on morphological identification by LM and SEM observation, correlated with its habitats and ecology and with the observed consistent dominance in travertines where it produces characteristic sedimentary patterns, we can confidently conclude that the organism identified as Phormidium incrustatum (Nägeli) Gomont is genetically identical with Isolate 8 obtained in this study. Cyanobacterial taxonomy is in a state of rapid changes by introduction of phylogenetic criteria based mostly on 16S rRNA gene sequencing. The taxonomic revisions are generally based on cultures with new taxa described on the basis of gaps in the sequence record $[63,64]$. Our results document the need to closely compare the sequences of cultures and corroborate their identity with those obtained from (direct) sequencing of field populations.

\section{The Role of Phormidium incrustatum}

The most important contribution of $P$. incrustatum and other similarly specialised microorganisms to the formation of travertines lies in their observed habit to grow in rapids where they promote entrapment and binding of suspended particles and cause sediment accumulation. Their activity causes lateral diversion of the water flow as well as an even, lateral distribution of sediment across the riverbed so as to form travertine barriers, thus having a major sedimentological and geologically rapid landscape-modifying impact. The barriers differentiate the river flow longitudinally into a series of lentic and lotic (lakes and waterfalls) environments each with a variety of microbial habitats and ecological niches $[18,20]$.

Microbial photosynthesis, including that of $P$. incrustatum, is expected to have contributed to the calcification process [65], but is considered local, and secondary in relation to $\mathrm{CO}_{2}$ supersaturation and degassing toward the equilibrium with the atmosphere, and so would be the seasonal effects of temperature [66]. The relatively low levels of carbonate saturation in the Hoyoux system may have been responsible for the dominance of a single cyanobacterium in relation to other compared travertine systems, which show a higher diversity of prokaryotic and eukaryotic microorganisms that are subjected to calcification. Biocalcification appears to be a genetic trait, provided that optimal chemical conditions of carbonate saturation are present, as some taxa sharing the same microenvironment calcify while others do not $[57,65,67]$ or may specifically require higher carbonate saturation levels. For example, a different and species-specific carbonate encrustation was observed in various cyanobacteria and chlorophytes in more diversified travertine systems [20,67,68]. The dominance of $P$. incrustatum in various habitats of the Hoyoux system offered a relatively simple microbial model, where calcification is restricted to one dominant cyanobacterium, while other microorganisms remained uncalcified.

The particular contribution by $P$. incrustatum involves mineral nucleation. There is evidence that the EPS produced by this organism competes successfully in attracting new molecules of calcium carbonate from the surrounding solution even in the presence of active carbonate mineral surfaces (see Fig. 7). The ability of $P$. incrustatum to initiate nucleation of carbonate on its own organic product (EPS) starts a mineralisation process that complies with a biological rather than mineral template (Figs. $7 \mathrm{~d}$, e and $8 \mathrm{e}, \mathrm{g}$ ).

The calcification appeared to be limited to the external surfaces or the outer layer of cyanobacterial sheaths, while leaving the lumen uncalcified and hollow (Figs. 7e, f and $9 a)$, contributing to the porosity of the deposit. The calcification expanding from the outer surfaces of EPS sheaths is 
consistent with the light-microscopic images (Fig. 5a, b). After the carbonate was removed by dissolution in dilute $\mathrm{HCl}$, the external surfaces of the extracted sheaths were not smooth, but covered by minute irregularly distributed dots, some of which may have marked the positions of calcite nucleation sites. In contrast, the interior surfaces of sheaths were smooth as seen in LM as well as in SEM images (Fig. 7c-f). This observation raised the question about the functional distinction between internal and external surfaces of the EPS sheath regarding carbonate nucleation capacity. The resolution of this question came from the study of the dynamics of oncoids rolling in the currents between barriers, which became externally abraded. As a consequence, the broken tubules become internally calcified as their interior was accessed by the carbonate-supersaturated environmental water (Fig. 8h). The above findings show that the EPS sheath of $P$. incrustatum is externally and internally uniform with respect to the attraction of carbonate cations and promotion of crystal nucleation. This is evident also by the fact that the precipitate in the interior of broken tubules started at the internal sheath surface and then proceeds to fill the lumen of the tubule. Thus, the lack of precipitate in the interior of most tubules can be explained by the fact that they remained sealed, initially by the resident trichomes and later by cementation, and thus not accessible to external carbonate-supersaturated water.

The motility of Phormidium trichomes constitutes an adaptive response property that provides the organism with the ability to avoid environmental hazards, in this case to escape the burial by their own calcified sheaths [68] and by other mineral precipitates derived from supersaturated interstitial waters. This property, if not shared by other microbial constituents, provides a critical competitive advantage, which is consistent with the observed dominance of this organism in the travertines. In the ecological sense, the travertines may be considered extreme environments, where the rates of encrustation and carbonate accumulation constitute the main competitive pressure and a limiting parameter. During most of its activity, the trichome is close to the exit of the tubule, gliding up and down within its polysaccharide sleeve and ready to move out and upward with the advancement of carbonate deposition. Its presence acts at the same time as a plug, preventing carbonate precipitation in the interior of its tubule.

The combination of gliding motility and the ability to promote carbonate precipitation of $P$. incrustatum constitutes a mechanism that may explain the observed different textures of the carbonate crust. These appear to be due to cyanobacterial growth response to water flow and impact. The porous velvet crust with diverging tubules was found in sections with slow to moderate water flow, where the maximum carbonate accretion took place at the tips of cyanobacterial filaments (Fig. 7a), which were able to grow in any direction, as long as the rate of environmental precipitation (cementation) remained low (e.g. Fig. 7 g). However, the high water impact in cascades, accompanied by elevated rates of environmental calcification, requires a different response. Phormidium trichomes respond by gliding upward to escape the burial, assuming upright position while keeping the pace with the carbonate accretion of the crust. Like other filamentous cyanobacteria, $P$. incrustatum reproduces by fragmentation into hormogonia that glide away and start another colony, but the residence time of individual filaments and maintenance of an intact tubule may be considerable as evident from the length of empty tubules inside the consolidated travertines (Figs. 8f, 9a).

\section{Fossilisation Capacity and Early Diagenesis}

The analysis of Hoyoux travertine using Raman spectroscopy (Fig. 10) confirmed that carbonate deposition does not support preservation and fossilisation of organic compounds as it promotes their complete aerobic decomposition. It did demonstrate, however, the relative recalcitrance in degradation of EPS and UV absorbing pigments that have a better chance to preserve and fossilise.

In addition, the decomposition of organic matter, once incorporated in travertine, seems to have contributed to early diagenetic alteration of the deposited carbonate. The changes were noticed in a zone of recrystallised mineral fabric along the contact between the carbonate deposit and the encrusted submerged twigs (Figs. 3d, 4f and 9b) with details showing large outward diverging crystal units with pseudo-stromatolite lamination (Fig. 9f, g). Similar diagenetic changes have been observed in fossil travertine of Italy, including large crystal units that still preserved tubular patterns of Phormidium on the periphery $[20,33]$ and pseudo-stromatolite layering inside recrystallised units [20]. The Phormidium imprint patterns are comparable with those in modern travertine of the Plitvice Lakes system in Croatia, and they are quite similar to those we now recorded in Hoyoux travertine.

The transitions between the zones with different carbonate textures (Fig. 9b) are abrupt, marking interruptions or changes in the process of sediment accretion, including possible differences in the extent or nature of diagenetic alterations in each of the observed zones. The zonal distribution of porosity due to density and orientation of calcareous tubules probably reflects the seasonal changes in water flow providing different conditions that promote microbial growth and calcification. The layers immediately surrounding the embedded wooden branches, however, reflect rather the onset of early diagenesis including recrystallisation of the carbonate fabric that modified the texture of the deposit and obliterated the traces left by the original organismal activity. These alterations are likely triggered by the processes of microbial degradation of the incorporated branches and thus proceed in the opposite direction of the accruing travertine deposition. The encrusted twigs 
provide an overview of early diagenetic changes within a rapidly progressing calcification process. Early onset of carbonate diagenesis has been observed in marine environments in corals, where it occurred during the coral growth [69].

\section{Conclusions}

Our results show that the calcareous crust formation and increase of travertine barriers of the Belgian rivers Hoyoux and Triffoy are guided by growth prevalence of a highly adapted cyanobacterium, identified as Phormidium incrustatum (Nägeli) Gomont, which has been isolated in culture. Both field populations and cultured clones were sequenced and found identical. The chemical composition of the waters was conducive to $\mathrm{CaCO}_{3}$ precipitation and the loss of carbonate from the solution was linked with $\mathrm{CO}_{2}$ degassing as measured by $\mathrm{pCO}_{2}$ difference before and after each of the studied cascades. The contribution of microbial photosynthesis to the carbonate precipitation, including that of Phormidium, is expected to be minor relative to that of $\mathrm{CO}_{2}$ degassing toward establishing carbonate chemical equilibrium with the atmosphere. The main contribution by $P$. incrustatum as a predominant cyanobacterium involves mineral nucleation. The established network of calcified filaments also acts as a filter that entraps suspended particles, which, together with calcification, contributes to the process of travertine accumulation. The response and competitiveness of this and other microorganisms to grow in rapids determine the location of travertine deposition. Special adaptations permitted the organisms to promote rapid sediment deposition and survive the process of burial while excluding potential competitors from such habitats. As these conditions permit survival of a selected group of organisms with exclusion of others, the travertine systems may be considered extreme environments. The most important biogenic impact of microorganisms associated with travertines is at the level of sedimentation. As these organisms settle preferentially in turbulent waters, they act as guides for sediment distribution and thereby profoundly modify the accretion of travertine deposit, so that the river ultimately differentiates into new alternating habitats such as pools and waterfalls each with its particular microhabitats and ecological niches.

Acknowledgements We acknowledge the Marie Curie COFUNDBeIPD for fellowship to J.K., the FRS-FNRS (Fonds De La Recherche Scientifique) grant to S.G. for sabbatical stay in A.W. and E.J.J.'s laboratories, the FNRS credit CR.CH.10-11-1.5139.11 and FRFC 2.4570.09, the FP7 ERC Stg ELiTE and the Belspo IAP PLANET TOPERS to E.J.J. and ERC postdoc to J.-Y.S. Collaborative field research support to S.G. and S.J.L. was provided by the National R\&D Project hosted by the National Research Institute of Cultural Heritage in Cultural Heritage Administration, Korea. International collaboration was supported by Alexander-von Humboldt Foundation, Bonn and Hanse Institute for Advanced Studies, Delmenhorst to S.G. We are grateful to E. Poty for guidance in the field and A. Beulen and S. Petrovic for assistance in field sampling and laboratory analysis. The authors thank the Centre of Aid for Research and Education in Microscopy of the University of Liege (CAREM-ULg) for providing access to performant equipment in electron microscopy. The water discharge data was freely provided by Service public de Wallonie, Direction générale opérationnelle Mobilité et Voies hydrauliques, Direction de la Gestion hydrologique intégrée, Service d'Etudes Hydrologiques (SETHY). A.V.B. is senior research associate and A.W. is research associate of the FRS-FNRS.

\section{References}

1. Castenholz RW, Rippka R, Herdman M, Wilmotte A (2001) Subsection III. (Formerly Oscillatoriales Elenkin 1934). In: Garrity GM (ed) Bergey's manual of systematic bacteriology, 2nd edn. Springer, New York, pp. 539-562

2. Schirrmeister BE, de Vos JM, Antonelli A, Bagheri HC (2013) Evolution of multicellularity coincided with increased diversification of cyanobacteria and the Great Oxidation Event. Proc. Natl. Acad. Sci. 110:1791-1796

3. Hofmann HJ (1976) Precambrian microflora, Belcher Islands, Canada: significance and systematics. J Palaeontol 50:1040-1073

4. Golubic S, Hoffmann HJ (1976) Comparison of modern and midPrecambrian Entophysalidaceae (Cyanophyta) in stromatolitic algal mats: cell division and degradation. J Palaeontol 50:1074-1082

5. Knoll AH, Golubic S (1992) Proterozoic and living cyanobacteria. In: Schidlowski A (ed) Early organic evolution: implications for mineral and energy resources. Springer, Berlin, pp. 450-462

6. Tomitani A, Knoll AH, Cavanaugh CM, Ohno T (2006) The evolutionary diversification of cyanobacteria: molecular-phylogenetic and paleontological perspectives. P Natl Acad Sci USA 103:54425447

7. Butterfield NJ (2015) Proterozoic photosynthesis, a critical review. Palaeontology 58:953-972

8. Walter MR (1976) Stromatolites, Developments in Sedimentology 20. Elsevier, Amsterdam pp. 790

9. Riding R (1991) Classification of microbial carbonates. In: Riding R (ed) Calcareous algae and stromatolites. Springer, Berlin, pp. 21-51

10. Tewari V, Seckbach J (2011) Stromatolites: interaction of microbes with sediments. Series: Cellular Origin, Life in Extreme Habitats and Astrobiology 18. Springer, Berlin, p. 751

11. Vincent WF (2000) Cyanobacterial dominance in the polar regions. In: Whitton BA, Potts M (eds) The ecology of cyanobacteria. Springer, Dordrecht, pp. 321-340

12. Javaux EJ (2006) Extreme life on past and present Earth, and possibly beyond. Res. Microbiol. 157:37-48

13. Brandes M, Albach DC, Vogt JC, Mayland-Quellhors E, MendietaLeiva G, Golubic S, Palinska KA (2015) Supratidal extremophiles - cyanobacterial diversity in the rock pools of the Croatian Adria. Microb. Ecol. 70(4):876-888

14. Pentecost A (1995) The Quaternary travertine deposits of Europe and Asia Minor. Quaternary Sci Rev 14:1005-1028

15. Ford TD, Pedley HM (1996) A review of tufa and travertine deposits of the world. Earth-Sci. Rev. 41:117-175

16. Liu Z, Li Q, Sun H, Liao C, Li H, Wang J, Wu K (2006) Diurnal variations of hydrochemistry in a travertine-depositing stream at Baishuitai, Yunnan, SW China. Aquat. Geochem. 12:103-121

17. Arp G, Bissett A, Brinkmann N, Cousin S, De Beer D, Friedl T, Mohr KI, Neu TR, Reimer A, Shiraishi F, Stackebrandt E, Zippel B (2010) Tufa-forming biofilms of German karstwater streams: microorganisms, exopolymers, hydrochemistry and calcification. Geol. Soc. Lond., Spec. Publ. 336:83-118 
18. Golubic S (1969) Cyclic and noncyclic mechanisms in the formation of travertine. Verhandlungen des Internationalen Verein Limnologie 1:956-961

19. Golubic S (1964) Beitrag zur Kenntnis der Lichtverhaeltnisse in einigen oligotrophen Seen des Karstes (Light conditions in some oligotrophic lakes of the Karstic region). Carsus Jugoslavicus 4:27-46

20. Golubic S, Violante C, Plenković A, Grgasović T (2008) Travertines and calcareous tufa deposits: an insight into diagenesis. Geologia Croatica 61:363-378

21. Pedley HM (2000) Ambient temperature freshwater microbial tufas. In: Riding RE, Awramik SM (eds) Microbial sediments. Springer, Berlin, pp. 179-186

22. Burne RV, Moore LS (1987) Microbialites: organosedimentary deposits of benthic microbial communities. PALAIOS 2:241-254

23. Pentecost A (2005) Travertine. Springer, Berlin, Heidelberg, New York, p. 448

24. Allen D, Suchy M (2001) Geochemical evolution of groundwater on Saturna Island, British Columbia. Can J Earth Sci 38:1059-1080

25. Pereira S, Zille A, Micheletti E, Moradas-Ferreira P, de Philippis R, Tamagnini P (2009) Complexity of cyanobacterial exopolysaccharides: composition, structures, inducing factors and putative genes involved in their biosynthesis and assembly. FEMS Microbio Rev 33:917-941

26. De los Ríos A, Ascaso C, Wierzchos J, Fernandez-Valiente E, Quesada A (2004) Microstructural characterization of cyanobacterial mats from the McMurdo Ice Shelf, Antarctica. Appl Environ Microb 70:569-580

27. Kamennaya N, Ajo-Franklin C, Northen T, Jansson C (2012) Cyanobacteria as biocatalysts for carbonate mineralization. Minerals 2(4):338-364

28. Dupraz C, Reid R, Braissant O, Decho AW, Norman RS, Visscher P (2009) Processes of carbonate precipitation in modern microbial mats. Earth-Sci. Rev. 96:141-162

29. Chan C (2004) Microbial polysaccharides template assembly of nanocrystal fibers. Science 303:1656-1658

30. Shiraishi F, Reimer A, Bissett A, de Beer D, Arp G (2008) Microbial effects on biofilm calcification, ambient water chemistry and stable isotope records in a highly supersaturated setting (Westerhöfer Bach, Germany). Palaeogeogr Palaeocl 262:91-106

31. Bartley JK (1996) Actualistic taphonomy of Cyanobacteria: implications for the Precambrian fossil record. PALAIOS 11:571-586

32. Golubic S, Fischer AG (1975) Ecology of calcareous nodules forming in Little Connestoga Creek near Lancaster, Pennsylvania. Verhandlungen des Internationalen Verein Limnologie 19:2315-2323

33. Golubic S, Violante C, Ferreri V, D'Argenio B (1993) Algal control and early diagenesis in Quaternary travertine formation (Rocchetta a Volturno, Central Apennines). In Barattolo F, De Castro P, Parente $M$ (eds) Studies on fossil benthic algae. Bollettino Società Paleontologica Italiana, Special Volume 1: pp. 231-247.

34. Lepot K, Deremiens L, Namsaraev Z, Compère P, Gérard E, Verleyen E, Tavernier I, Hodgson DA, Wilmotte A, Javaux EJ (2014) Organo-mineral imprints in fossil cyanobacterial mats of an Antarctic lake. Geobiology 12(5):424-450

35. Cousin S, Stackebrandt E (2010) Spatial bacterial diversity in a recent freshwater tufa deposit. Geomicrobiology J 27:275-291

36. Brinkmann N, Hodac L, Mohr KI, Hodacova A, Jahn R, Ramm J, Hallmann C, Arp G, Friedl T (2015) Cyanobacteria and diatoms in biofilms of two karstic streams in Germany and changes of their communities along calcite saturation gradients. Geomicrobiology $\mathrm{J}$ 32:255-274

37. Franco B, Houbrechts G, Van Campehout JE, Hallot E, Petit F (2008) Etude géomorphologique des barrages de travertin du Hoyoux. Bulletin de la Société géographique de Liège 50:45-56
38. Borges AV, Darchambeau F, Teodoru CR, Marwick TR, Tamooh F, Geeraert N, Omengo FO, Guérin F, Lambert T, Morana C, Okuku E, Bouillon S (2015) Globally significant greenhouse gas emissions from African inland waters. Nat. Geosci. 8:637-642

39. Abril G, Bouillon S, Darchambeau F, Teodoru CR, Marwick TR, Tamooh F, Omengo FO, Geeraert N, Deirmendjian L, Polsenaere P, Borges AV (2015) Technical Note: Large overestimation of $\mathrm{pCO}_{2}$ calculated from $\mathrm{pH}$ and alkalinity in acidic, organic-rich freshwaters. Biogeosciences 12(1):67-78

40. Gran G (1952) Determination of the equivalence point in potentiometric titrations of seawater with hydrochloric acid. Oceanol. Acta 5:209-218

41. Rodier J, Bazin C, Broutin JP, Chambon P, Champsaur H, Rodi L (2005) L'analyse de l'eau: eaux naturelles, eaux résiduaires, eau de mer. Paris. 8th edn, pp. 1381

42. Marshall CP, Javaux EJ, Knoll AH, Walter MR (2005) Combined micro-Fourier transform infrared (FTIR) spectroscopy and microRaman spectroscopy of Proterozoic acritarchs: a new approach to palaeobiology. Precambrian Res. 138(3-4):208-224

43. Storme JY, Golubic S, Wilmotte A, Kleinteich J, Velázquez D, Javaux EJ (2015) Raman characterization of the UV-protective pigment gloeocapsin and its role in the survival of cyanobacteria. Astrobiology 15:843-857

44. Stanier RY, Kunisawa R, Mandel M, Cohenbazire G (1971) Purification and properties of unicellular blue-green algae (order Chroococcales). Bacteriol. Rev. 35:171-205

45. Jungblut AD, Neilan BA (2006) Molecular identification and evolution of the cyclic peptide hepatotoxins, microcystin and nodularin, synthetase genes in three orders of cyanobacteria. Arch. Microbiol. 185:107-114

46. Nübel U, Garcia-Pichel F, Muyzer G (1997) PCR primers to amplify 16S rRNA genes from cyanobacteria. Appl Environ Microb 63:3327-3332

47. Taton A, Grubisic S, Brambilla E, Wit D, Wilmotte A (2003) Cyanobacterial diversity in natural and artificial microbial mats of Lake Fryxell (McMurdo Dry Valleys, Antarctica): a morphological and molecular approach. Appl Environ Microb 69:5157-5169

48. Hall TA (1999) BioEdit: a user-friendly biological sequence alignment editor and analysis program for Windows 95/98/NT. Nucl Acids Symp 41:95-98

49. Tamura K, Stecher G, Peterson D, Filipski A, Kumar S (2013) MEGA6: Molecular Evolutionary Genetics Analysis version 6.0. Mol. Biol. Evol. 30:2725-2729

50. Van de Peer Y, De Wachter R (1997) Evolutionary relationships among the eukaryotic crown taxa taking into account site-to-site rate variation in 18S rRNA. J. Mol. Evol. 45:619-630

51. Jukes TH and Cantor CR (1969) Evolution of protein molecules. In Munro HN (ed.) Mammalian protein metabolism. Academic Press, New York and London. Volume III Chapter 24

52. Grossman AR (2003) A molecular understanding of complementary chromatic adaptation. Photosynth. Res. 76:207-215

53. Tandeau de Marsac N (1977) Occurrence and nature of chromatic adaptation in cyanobacteria. J. Bacteriol. 130:82-91

54. Pentecost A (2003) Taxonomic identity, ecology and distribution of the calcite-depositing cyanobacterium Phormidium incrustatum (Oscillatoriaceae). Cryptogamie Algol 24:307-321

55. Bartrons M, Catalan J, Casamayor EO (2012) High bacterial diversity in epilithic biofilms of oligotrophic mountain lakes. Microb. Ecol. 64:860-869

56. Hašler $P$, Dvořak $P$, Johansen JR, Kitner $M$, Ondřej V, Pouličkova A (2012) Morphological and molecular study of epipelic filamentous genera Phormidium, Microcoleus and Geitlerinema (Oscillatoriales, Cyanophyta/ Cyanobacteria). Fottea 12(2):341-356 
57. Golubic S (1973) The relationship between blue-green algae and carbonate deposits. In: Carr N, Whitton BA (eds) The biology of blue-green algae. Blackwell, Oxford, pp. 434-472

58. Herman $\mathrm{SH}$, Lorah MM (1987) $\mathrm{CO}_{2}$ outgassing and calcite precipitation in falling spring creek, Virginia, USA. Chem. Geol. 62:251-262

59. Suda S, Watanabe MM, Otsuka S, Mahakahant A, Yongmanitchai W, Nopartnaraporn N, Liu Y, Day JG (2002) Taxonomic revision of water bloom-forming species of oscillatorioid cyanobacteria. Int $\mathrm{J}$ Syst Evol Micr 52:1577-1595

60. Schneider D, Reimer A, Hahlbrock A, Arp G, Daniel R (2015) Metagenomic and metatranscriptomic analyses of bacterial communities derived from a calcifying karst water creek biofilm and tufa. Geomicrobiol J. 32:316-331

61. Palińska KA, Abed RMM, Wendt K, Charpy L, Łotocka M, Golubic S (2012) Opportunistic cyanobacteria in benthic microbial mats of a tropical lagoon, Tikehau Atoll, Tuamotu Archipelago: minor in natural populations, major in cultures. Fottea 12:127-140

62. Richert L, Golubic S, De Le Gue R, Herve A, Payri C (2006) Cyanobacterial populations that build 'kopara' microbial mats in Rangiroa, Tuamotu Archipelago, French Polynesia. Europ J Phycol 41:259-279

63. Engene N, Hyukjae Choi EC, Ellisman MH, Komárek J, Gerwick WH (2012) Moorea producens gen. nov., sp. nov. and Moorea bouillonii comb. nov., tropical marine cyanobacteria rich in bioactive secondary metabolites. Int J Syst Evol Micr 62:1171-1178

64. Komárek J, Kaštovský J, Mareš J, Johansen JR (2014) Taxonomic classification of cyanoprokaryotes (cyanobacterial genera), using a polyphasic approach. Preslia 86:295-335

65. Merz-Preiss M (2000) Calcification in Cyanobacteria. In: Riding RE, Awramik SM (eds) Microbial sediments. Springer, Berlin, pp. 50-56

66. Srdoč D, Horvatinčić N, Obelić B, Krajcar-Bronić I, Sliepčević A (1985) Calcite deposition processes in karstwaters with special emphasis on the Plitvice Lakes, Yugoslavia (Croatian w. German and English summary). Krš Jugoslavije (Carsus Iugoslaviae) 11:101-204

67. Berrendero E, Arenas C, Mateo P, Jones B (2016) Cyanobacterial diversity and related sedimentary facies as a function of water flow conditions: example from the Monasterio de Piedra Natural Park (Spain). Sed Geol 337:12-28

68. Golubic S, Lee S-J, Browne KM (2000) Cyanobacteria: architects of sedimentary structures. In: Riding RE, Awramik (eds) Microbial sediments. Springer, Heidelberg-Berlin-New York, pp. 56-67

69. Le Campion-Alsumard T, Golubic S, Hutchings P (1995) Microbial endoliths in skeletons of live and dead corals: Porites lobata (Moorea, French Polynesia). Mar Ecol-Prog Ser 117:149-157 